\title{
A Review on the Life Cycle Assessment of Cellulose: From Properties to the Potential of Making It a Low Carbon Material
}

\author{
Firoozeh Foroughi ${ }^{1, *}$, Erfan Rezvani Ghomi ${ }^{2, *} \mathbb{C}$, Fatemeh Morshedi Dehaghi ${ }^{2}$, Ramadan Borayek ${ }^{1}$ and \\ Seeram Ramakrishna $2, *$ (D) \\ 1 Department of Materials Science and Engineering, Faculty of Engineering, National University of Singapore, \\ 9 Engineering Drive 1, Singapore 117576, Singapore; ramadan_abdelhamid@u.nus.edu \\ 2 Center for Nanotechnology and Sustainability, Department of Mechanical Engineering, National University \\ of Singapore, Singapore 117581, Singapore; morshedi.iut91@gmail.com \\ * Correspondence: firoozehforoughi@u.nus.edu (F.F.); erfanrezvani@u.nus.edu (E.R.G.); \\ seeram@nus.edu.sg (S.R.)
}

check for updates

Citation: Foroughi, F.; Rezvani Ghomi, E.; Morshedi Dehaghi, F.; Borayek, R.; Ramakrishna, S. A Review on the Life Cycle Assessment of Cellulose: From Properties to the Potential of Making It a Low Carbon Material. Materials 2021, 14, 714. https://doi.org/10.3390/ma14040714

Academic Editor: Fabrizio De Cesare Received: 28 December 2020

Accepted: 29 January 2021

Published: 3 February 2021

Publisher's Note: MDPI stays neutral with regard to jurisdictional claims in published maps and institutional affiliations.

Copyright: (c) 2021 by the authors. Licensee MDPI, Basel, Switzerland. This article is an open access article distributed under the terms and conditions of the Creative Commons Attribution (CC BY) license (https:// creativecommons.org/licenses/by/ $4.0 /)$.

\begin{abstract}
The huge plastic production and plastic pollution are considered important global issues due to environmental aspects. One practical and efficient way to address them is to replace fossilbased plastics with natural-based materials, such as cellulose. The applications of different cellulose products have recently received increasing attention because of their desirable properties, such as biodegradability and sustainability. In this regard, the current study initially reviews cellulose products' properties in three categories, including biopolymers based on the cellulose-derived monomer, cellulose fibers and their derivatives, and nanocellulose. The available life cycle assessments (LCA) for cellulose were comprehensively reviewed and classified at all the stages, including extraction of cellulose in various forms, manufacturing, usage, and disposal. Finally, due to the development of low-carbon materials in recent years and the importance of greenhouse gases (GHG) emissions, the proposed solutions to make cellulose a low carbon material were made. The optimization of the cellulose production process, such as the recovery of excessive solvents and using by-products as inputs for other processes, seem to be the most important step toward making it a low carbon material.
\end{abstract}

Keywords: nanocellulose; life cycle assessment; cradle-to-grave; low carbon materials; cradle-to-gate

\section{Introduction}

Due to environmental issues caused by the consumption of fossil resources and their depletion, the concept of sustainable development using environmentally innocuous materials is being adopted [1-3]. Cellulose is the most abundant biodegradable polymer available, having a total production capacity of $10^{11}-10^{12}$ tons each year [4]. The gross domestic product induced by the commercialization of nanocellulose, as a form of cellulose materials, is estimated to be around $\$ 600$ billion worldwide by 2020 [5]. The U.S Department of Energy predicts that renewable sources will supply $50 \%$ of necessary chemicals by 2050 [6]. Therefore, research on different aspects of cellulose products, their application in various industries, and their production techniques have increased. Due to the increasing consumption of cellulose products in recent years, one of the required fields of this research, as well as the purpose of this study, is the evaluation of environmental effects arising from the extraction of cellulose, fabrication processes of cellulose products, cellulose products use, and their end-of-life disposal. In this regard, life cycle analysis (LCA) is a powerful tool for assessing the cumulative environmental impact attributed to all the steps from extraction-manufacture-use-dispose of cellulose, in other words, cradle to grave. Based on these analyses, measures can be taken to minimize the environmental impact and develop low-carbon cellulosic materials $[7,8]$. 
Payen first discovered cellulose in 1838, and its molecular formula was determined to be $\mathrm{C}_{6} \mathrm{H}_{10} \mathrm{O}_{5}$ by elemental analysis. The structure of this polymer is a linear syndiotactic homopolymer formed by D-anhydroglucopyranose units (AGUs), which are joined by glycosidic bonds (as shown in Figure 1) [9]. The primary source of cellulose is plants such as wood, hemp, cotton, and linen, and it has been used as an energy source and construction materials for thousands of years [10-12]. Moreover, cellulose is produced from many microorganisms such as fungi and bacteria having the same chemical makeup as was studied by Brown in 1886 [13,14]. Bacterial cellulose differs from a plant in a degree of polymerization, purity, and characteristics [10,15-18]. It is clear that due to having three hydroxyl groups in the monomer structure, the formation of hydrogen bonds has a noticeable influence on directing the crystalline regions and, as a result, controlling the physical properties $[19,20]$. The presence of these hydroxyl groups also eases cellulose's chemical modification processes to obtain the cellulose derivatives that are useful for manufacturing new biopolymers with various applications [21-23].

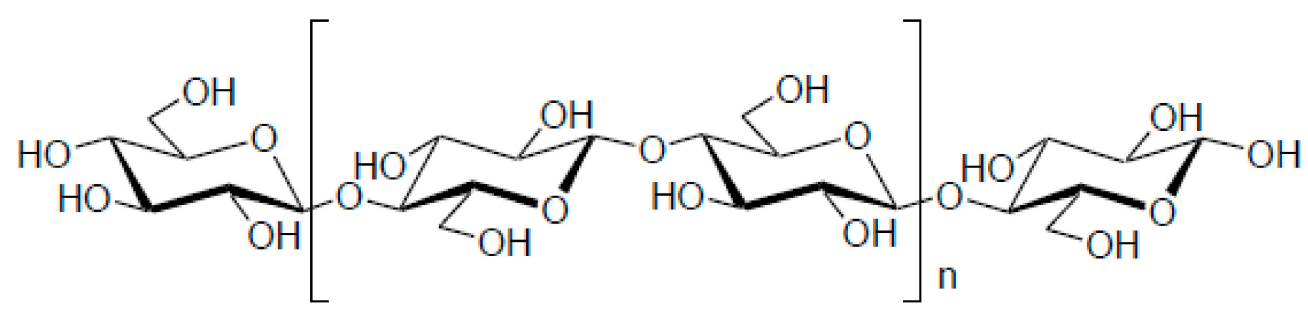

Figure 1. Structure of cellulose.

In this study, different cellulose forms are first investigated in terms of characteristics, manufacturing processes, applications, and their effects on the final products. According to recent research, the environmental impacts of various forms of cellulose, including cradle-to-gate and cradle-to-grave, are analyzed through LCA. Finally, after highlighting the challenges faced by the LCA of cellulose materials, some specific suggestions related to the development of low-carbon materials are expressed.

\section{Classification of Different Types of Cellulose}

Cellulose-based products are classified into three other groups based on the forms of cellulose, including (1) cellulose-derived monomer for biopolymers production, (2) products based on cellulose fiber and cellulose derivatives, and (3) products based on nanocellulose. Figure 2 shows three different cellulose forms, and their products, properties, and other applications are elaborated upon in the following sections.

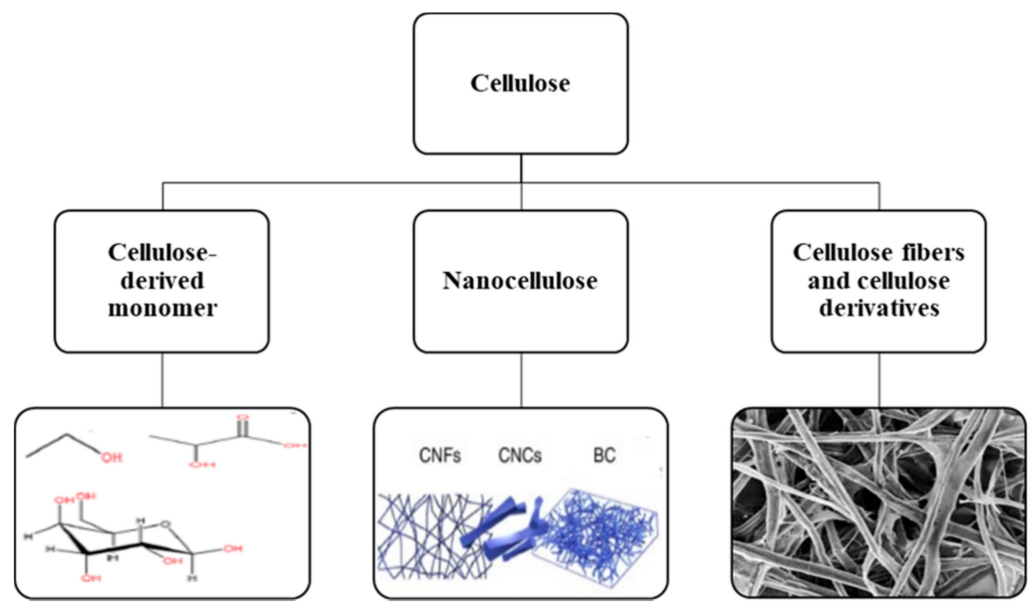

Figure 2. A general classification of different forms of cellulose. 


\subsection{Cellulose-Derived Monomer}

Glucose can be obtained by depolymerizing cellulose via enzymatic and acid-catalyzed hydrolysis. Then, they are used for polymer production. Glucose monosaccharides act as raw materials for the catalytic and biotechnological production of chemical and monomers such as methanol, ethanol, lactic acid (LA), sorbitol, 5-hydroxymethylfurfural (5-HMF), levulinic acid (LevA). These derived monomers can be used to synthesize sustainable polymers and copolymers [24]. Table 1 lists some chemicals and polymers with their production routes as obtained by the depolymerization of cellulose.

Table 1. Chemicals and monomer/polymer-based on cellulose and their processes.

\begin{tabular}{|c|c|c|c|c|}
\hline $\begin{array}{c}\text { Cellulose-Derived } \\
\text { Monomer }\end{array}$ & Process & Polymer/Chemical Materials & Process & Ref. \\
\hline Ethanol & $\begin{array}{l}\text { Conversion to ethanol } \\
\text { by fermentation }\end{array}$ & $\begin{array}{l}\text { Ethylene, Polyethylene, } \\
\text { polyethylene oxide, polyvinyl } \\
\text { chloride, polystyrene }\end{array}$ & $\begin{array}{l}\text { Production of ethylene } \\
\text { by ethanol dehydration } \\
\text { at high temperatures }\end{array}$ & {$[25,26]$} \\
\hline $\begin{array}{l}\text { Sorbitol or sugar } \\
\text { alcohols }\end{array}$ & $\begin{array}{l}\text { Chemocatalytic } \\
\text { transformations of } \\
\text { glucose: hydrogenation } \\
\text { or direct } \\
\text { hydrogenolysis }\end{array}$ & $\begin{array}{l}\text { Sorbitol, Isosorbide (base of } \\
\text { polymers such as polyesters, } \\
\text { polyamides, polycarbonates, } \\
\text { polyurethanes, etc.), glycerol, } \\
\text { propylene, ethylene glycol }\end{array}$ & $\begin{array}{l}\text { Dehydration } \\
\text { hydrogenolysis or } \\
\text { hydrodeoxygenation } \\
\text { reactions }\end{array}$ & [27] \\
\hline LA & Fermentation of sugars & $\begin{array}{l}\text { (1) Acrylic acid, 2,3-pentanedione, } \\
\text { acetaldehyde, and propionic acid } \\
\text { (2) propylene glycol, } \\
\text { polycarbonates, polyurethanes, } \\
\text { and polypropylene oxide) or } \\
\text { pyruvic acid } \\
\text { (3) alkyl lactates } \\
\text { (4) PLA }\end{array}$ & $\begin{array}{l}\text { (1) Dehydration of LA } \\
\text { combined with other } \\
\text { reactions } \\
\text { (2) Reduction and } \\
\text { oxidation } \\
\text { (3) Esterification } \\
\text { (4) Direct } \\
\text { polycondensation, } \\
\text { ring-opening } \\
\text { polymerization }\end{array}$ & {$[26,28,29]$} \\
\hline 5-HMF & $\begin{array}{l}\text { Acid-catalyzed } \\
\text { dehydration of glucose }\end{array}$ & $\begin{array}{l}\text { Furan-based monomers such as } \\
\text { BHF and FDC }\end{array}$ & $\begin{array}{l}\text { FDC: oxidation of HMF } \\
\text { BHF: hydrogenation by } \\
\text { NaBH4 or catalytic } \\
\text { process by hydrogen } \\
\text { over } \mathrm{Cu} \text { or } \mathrm{Pt}\end{array}$ & {$[26,30,31]$} \\
\hline LevA & - & $\begin{array}{l}\text { (1) } \gamma \text { MMBL, } \beta \text { MMBL which are } \\
\text { substitutes for the } \\
\text { petroleum-based methacrylate } \\
\text { monomers } \\
\text { (2) constituents of PHA: } 3 \mathrm{HV}, 4 \mathrm{HV} \\
\text { and their copolymers such as } \\
\text { PHBV composites }\end{array}$ & $\begin{array}{l}\text { (1) Two steps process } \\
\text { developed by DuPont, } \\
\text { condensation of } \\
\text { 3-methyl- } \gamma \text { - } \\
\text { butyrolactone } \\
\text { (2) Conversion to } 3 \mathrm{HV} \\
\text { and } 4 \mathrm{HV} \text { by } \\
\text { microorganisms }\end{array}$ & [32-34] \\
\hline Itaconic acid & $\begin{array}{l}\text { Fermentation of } \\
\text { glucose by fungi }\end{array}$ & $\begin{array}{l}\text { New polyester based on poly } \\
\text { (itaconic acid), polyamide }\end{array}$ & $\begin{array}{l}\text { Transformation into } \\
\text { itaconic diamide or } \\
\text { 2-methyl-1,4- } \\
\text { butanediamine }\end{array}$ & [31] \\
\hline
\end{tabular}

LA: Lactic acid, PLA: Polylactic acid, FDC: 2,5-furan dicarboxylic acid, BHF: 2,5-bis(hydroxymethyl)furan, 3HV: 3-hydroxyvalerate, 4HV: 4-hydroxyvalerate, LevA: levulinic acid, 5-HMF: 5-hydroxymethylfurfural, $\gamma$ MMBL: $\gamma$-methyl- $\alpha$-methylene- $\gamma$-butyrolactone, $\beta$ MMBL: $\beta$-methyl- $\alpha$-methylene- $\gamma$-butyrolactone.

\subsection{Cellulose Fibers and Derivatives}

In recent decades, cellulose fibers and cellulose derivatives have been widely used in the production of biocomposites and films as filler, matrix, or both. Cellulose plant fibers consist of a primary cell wall and three secondary cell walls. The cell walls are made up of bundles of microfibrils with a diameter in the order of $10 \mu \mathrm{m}$ and are present in the 
lignin-hemicellulose matrix [35]. Many factors influence the properties of cellulose fibers, such as fiber structure, microfibrils angle, cell dimensions, and defects of plants, which differ for different plants and also parts of the plant [36]. Furthermore, chemical treatment is considered as a modification method of the plant fibers properties, which develops opportunities for new biopolymers with improved physical and chemical properties $[37,38]$. Among these derivatives, cellulose esters, ethers and acetate are the most common.

Recently, all-cellulose composites have emerged as a new class of biocomposites. These nanocomposites have received huge attention because of the use of chemically similar cellulosic materials as matrix and filler that can eliminate the problem of matrix-filler adhesion and interactions [39]. The cellulose used in these nanocomposites can be in the form of fibers or nanocellulose, which will be discussed in the next section. The results of using this form of cellulose in biocomposites and their subsequent applications are summarized in Table 2.

Table 2. The effects and applications of cellulose fibers and their derivatives.

\begin{tabular}{|c|c|c|c|c|}
\hline $\begin{array}{l}\text { Cellulose-Based } \\
\text { Composites }\end{array}$ & Function of Cellulose & Results & Application & Ref. \\
\hline $\begin{array}{l}\mathrm{BiOBr} / \text { regenerated } \\
\text { cellulose fibers } \\
\text { composite film }\end{array}$ & Matrix & $\begin{array}{l}\text { Exhibiting efficient photocatalytic activity by } \\
\text { providing a cavity for particles and extending } \\
\text { the specific surface area. }\end{array}$ & $\begin{array}{l}\text { A green catalyst for } \\
\text { light degradation of } \\
\text { phenol }\end{array}$ & [40] \\
\hline $\begin{array}{l}\text { Graphene Oxide } \\
\text { (GO)/cellulose fibers } \\
\text { composite film }\end{array}$ & Matrix & $\begin{array}{l}\text { Improving mechanical properties: tensile } \\
\text { strength }(78 \%) \text {, elongation at break }(172 \%) \text {, } \\
\text { and fracture energy ( } 397 \%) \text { of composite film } \\
\text { containing 0.5 wt } \% \text { GO in comparison with } \\
\text { the neat cellulose film. } \\
\text { Excellent ultraviolet-shielding properties. }\end{array}$ & $\begin{array}{l}\text { Packaging and } \\
\text { protective industry }\end{array}$ & [41] \\
\hline $\begin{array}{l}\text { MWCNT/regenerated } \\
\text { cellulose fibers film }\end{array}$ & Matrix & $\begin{array}{l}\text { Improvement of ductility and toughness due } \\
\text { to the favorable interaction of CNT-cellulose } \\
\text { Enhancing thermal stability } \\
\text { Effective sensing capability to tensile strain, } \\
\text { temperature, and environmental humidity. }\end{array}$ & $\begin{array}{l}\text { Biotechnological } \\
\text { applications }\end{array}$ & [42] \\
\hline $\begin{array}{l}\text { Carbon nanotube } \\
(\mathrm{CNT}) / \text { cellulose fibers } \\
\text { composite papers }\end{array}$ & Matrix & $\begin{array}{l}\text { Enhancing electrical properties and thermal } \\
\text { stabilities Ability to absorb microwaves in the } \\
\text { range of } 10.5 \mathrm{GHz} \text {. }\end{array}$ & $\begin{array}{l}\text { Electromagnetic } \\
\text { shields and } \\
\text { biotechnological } \\
\text { applications }\end{array}$ & [43] \\
\hline $\begin{array}{l}\text { Cellulose ac- } \\
\text { etate/Hydroxyapatite } \\
\text { composite }\end{array}$ & Matrix & $\begin{array}{l}\text { Having uniform film and good ductility } \\
\text { Adsorbing bisphenol A from polluted water } \\
\text { Existence of strong interaction between CA } \\
\text { and Hap. }\end{array}$ & $\begin{array}{l}\text { Absorption of } \\
\text { bisphenol A }\end{array}$ & [44] \\
\hline $\begin{array}{l}\text { Cellulose } \\
\text { fiber/high-density } \\
\text { polyethylene composite }\end{array}$ & Filler & $\begin{array}{l}\text { Improvement in thermal and mechanical } \\
\text { properties compared with neat HDPEIncrease } \\
\text { of Young modulus by } 122.4 \% \text { in the } \\
\text { composite containing } 40 \mathrm{wt} \% \text { cellulose fiber. }\end{array}$ & - & [45] \\
\hline $\begin{array}{l}\text { Polypyrrole/cellulose } \\
\text { fiber composite }\end{array}$ & Filler & $\begin{array}{l}\text { Reduction in highly toxic } \mathrm{Cr}(\mathrm{IV}) \text { to less toxic } \\
\qquad \mathrm{Cr}(\mathrm{III}) .\end{array}$ & $\begin{array}{c}\mathrm{Cr}(\mathrm{VI}) \\
\text { detoxification of } \\
\text { contaminated water }\end{array}$ & [46] \\
\hline $\begin{array}{l}\text { Polypropylene/cellulose } \\
\text { fiber composite }\end{array}$ & filler & $\begin{array}{l}\text { Obtaining the best result of flame retardancy } \\
\text { for silylation treatment of cellulose fibers. }\end{array}$ & $\begin{array}{l}\text { Flame retardant } \\
\text { composites }\end{array}$ & [47] \\
\hline $\begin{array}{l}\text { Cellulose lyocell } \\
\text { fibers/cellulose acetate } \\
\text { butyrate composite }\end{array}$ & Matrix/filler & $\begin{array}{l}\text { Increase in Young modulus for composite } \\
\text { containing } 34.8(v / v)(4 \mathrm{GPa}) \text { compared with } \\
\text { cellulose acetate butyrate ( } 2 \mathrm{GPa}) \\
\text { Increase in tensile strength, water absorption, } \\
\text { and biodegradability. }\end{array}$ & Water absorption & [48] \\
\hline
\end{tabular}


Table 2. Cont.

\begin{tabular}{|c|c|c|c|c|}
\hline $\begin{array}{l}\text { Cellulose-Based } \\
\text { Composites }\end{array}$ & Function of Cellulose & Results & Application & Ref. \\
\hline $\begin{array}{l}\text { Regenerated } \\
\text { cellulose/Cellulose } \\
\text { nanowhiskers film } \\
\text { composite }\end{array}$ & Matrix/filler & $\begin{array}{l}\text { Having transparent to visible light film } \\
\text { nanocomposites } \\
\text { Improvement in mechanical properties, for } \\
\text { example, tensile strength and modulus, could } \\
\text { reach } 124 \mathrm{MPa} \text { and } 5 \mathrm{GPa} \text {. }\end{array}$ & $\begin{array}{l}\text { Biomaterials and } \\
\text { food ingredients }\end{array}$ & [49] \\
\hline $\begin{array}{l}\text { Regenerated } \\
\text { cellulose/pulp fibres } \\
\text { composites }\end{array}$ & Matrix/filler & $\begin{array}{l}\text { A two-fold increase in tensile strength and } \\
\text { elastic modulus in comparison with } \\
\text { epoxy-cellulose composites. }\end{array}$ & - & [50] \\
\hline $\begin{array}{l}\text { All-Cellulose } \\
\text { composites containing } \\
\text { microcrystalline }\end{array}$ & Matrix/filler & $\begin{array}{l}\text { Improving mechanical properties, e.g., tensile } \\
\text { strength tensile modulus. }\end{array}$ & - & [51] \\
\hline $\begin{array}{l}\text { All-Cellulose } \\
\text { composites containing } \\
\text { bacterial cellulose }\end{array}$ & Matrix/filler & $\begin{array}{l}\text { Providing a high toughness of } 16 \mathrm{MJ} / \mathrm{m}^{3} \\
\text { Nanocomposites with optimum immersion } \\
\text { time have a tensile strength of } 411 \mathrm{MPa} \text { and a } \\
\text { Young modulus of } 18 \mathrm{GPa} \text {. }\end{array}$ & - & [52] \\
\hline $\begin{array}{l}\text { All-Cellulose aerogels } \\
\text { containing } \\
\text { microcrystalline }\end{array}$ & Matrix/filler & $\begin{array}{l}\text { High mechanical properties, for example, for } \\
\text { aerocellulose containing } 10-15 \% \text { cellulose, } \\
\text { flexural strength and stiffness reached } \\
8.1 \mathrm{MPa} \text { and } 280 \mathrm{MP} \text {, respectively. }\end{array}$ & - & [53] \\
\hline $\begin{array}{l}\text { Cellulose diac- } \\
\text { etate/nanofibrillated } \\
\text { cellulose film } \\
\text { nanocomposites }\end{array}$ & Matrix/filler & $\begin{array}{l}\text { Increase in tensile strength, Young modulus, } \\
\text { and strain at the break by } 102,80 \text {, and } 32 \% \text {, } \\
\text { respectively, with the addition of } 15 \% \\
\text { nanofibrillated cellulose. } \\
\text { Reduction in thermal stability and } \\
\text { transparency by incorporation of } \\
\text { nanofibrillated cellulose. }\end{array}$ & $\begin{array}{l}\text { High-performance } \\
\text { nanocomposites }\end{array}$ & [54] \\
\hline $\begin{array}{l}\text { All-Cellulose } \\
\text { composites containing } \\
\text { alpha and wood pulps } \\
\text { fibers }\end{array}$ & Matrix/filler & $\begin{array}{c}\text { By the addition of } 38-50 \text { wt. } \% \text { of reinforcing } \\
\text { fibers, an increase to } 4 \mathrm{GPa} \text { and } 14-16 \mathrm{MPa} \text { for } \\
\text { Young modulus and yield stress was } \\
\text { observed, respectively. }\end{array}$ & - & [55] \\
\hline
\end{tabular}

\subsection{Nanocellulose}

In recent years, attention towards a novel form of cellulose is increasing considerably because of the attractive properties of nano-scale materials. There are some specific characteristics of nanocellulose, including excellent mechanical properties, high aspect ratio, and good biodegradability [24,56]. There are two different classifications for cellulose nanomaterials: a classification based on the size and appearance of nanocellulose, and the other is based on the preparation methods and raw materials [35]. Figure 3 illustrates the classification of cellulose nanomaterials based on size and appearance. 


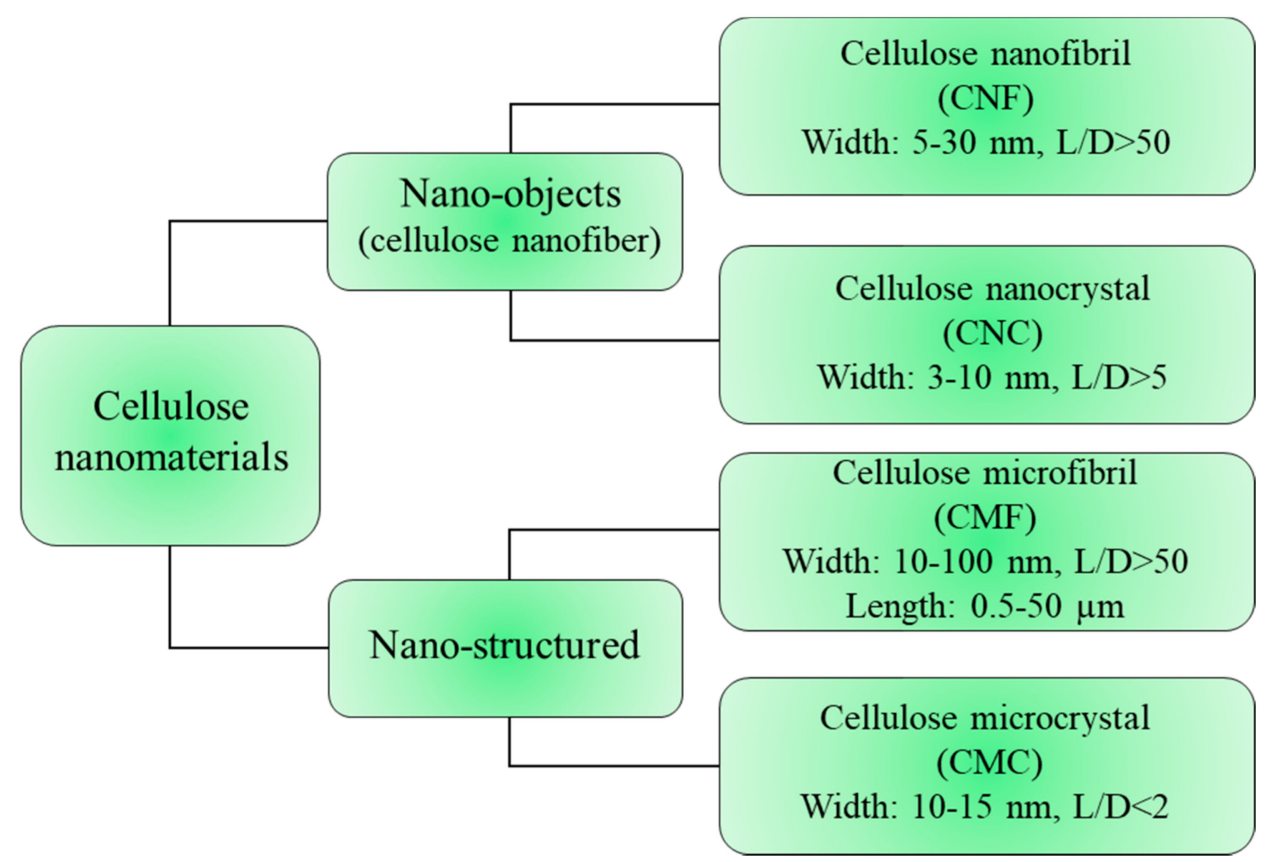

Figure 3. Classification of cellulose nanomaterials based on size and appearance.

Furthermore, according to different preparation methods and raw materials, nanocellulose can be divided into three subcategories. This classification includes (1) cellulose microfibrils $(\mathrm{CMF})$, or nanofibrils $(\mathrm{CNF})$ prepared from plant fibers through chemical, mechanical, or combined treatments [57,58], (2) nanocrystalline cellulose (CNC) (sometimes called nanowhiskers) produced by raw materials including plant, animal, and bacterial resources through acid hydrolysis, and (3) bacterial nanocellulose (BNC) prepared from certain bacteria [5]. Figure 4 shows the images of these types of nanocellulose, and Table 3 provides some results and applications of these forms of nanocellulose.
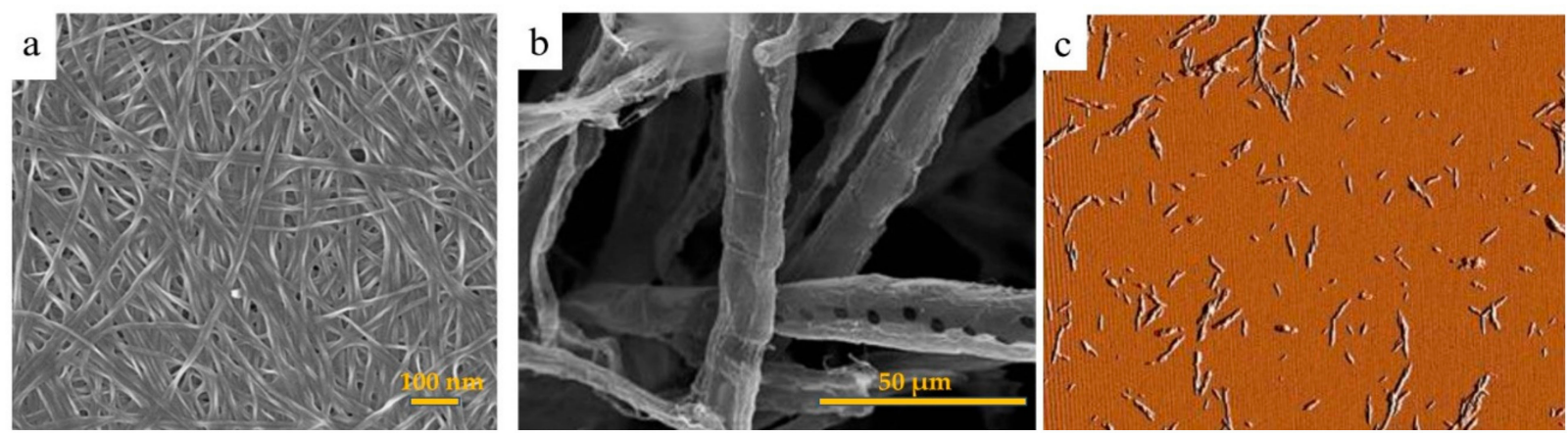

Figure 4. Scanning electron micrographs of (a) BNC [59], (b) Kraft bamboo pulp MFC [60], and (c) Atomic force microscopy (AFM) amplitude image of CNC (scan size: $5 \mu \mathrm{m}$ or 5 by 5 microns) [61]. 
Table 3. Effects and applications of different forms of nanocellulose.

\begin{tabular}{|c|c|c|c|c|}
\hline Type of Nanocellulose & Other Components & Results & $\begin{array}{c}\text { Product } \\
\text { Forms/Application }\end{array}$ & Ref. \\
\hline $\mathrm{CNF}$ & $\begin{array}{l}\text { Zeolites, polyethylene } \\
\text { glycol, } \mathrm{CaCl}_{2}\end{array}$ & $\begin{array}{l}\text { Improving tensile strength by } 10 \mathrm{MPa} \\
\text { Enhancing bending flexibility } \\
\text { Removing thiols below the human } \\
\text { olfactory threshold. }\end{array}$ & $\begin{array}{l}\text { Film/air purification } \\
\text { for odor removal }\end{array}$ & [62] \\
\hline $\mathrm{CNF}$ & $\begin{array}{l}\text { 3-mercaptopropyl- } \\
\text { trimethoxysilane }\end{array}$ & $\begin{array}{c}\text { Showing high mechanical and } \\
\text { chemical stabilities } \\
\text { Recovering } 94 \% \text { of its shape in the } \\
\text { water. }\end{array}$ & $\begin{array}{l}\text { Sponge/adsorption of } \\
\text { copper }\end{array}$ & [63] \\
\hline $\mathrm{CNF}$ & Silica nanoparticles & $\begin{array}{l}\text { A slight reduction in tenacity and } \\
\text { preservation of Young's } \\
\text { modulusEnhancing char formation } \\
\text { due to the presence of SNP on the } \\
\text { CNF surface. }\end{array}$ & Fiber/fire retardants & [64] \\
\hline $\mathrm{CNF}$ & - & $\begin{array}{l}\text { Promising new piezoelectric material } \\
\text { for sensors and actuators. }\end{array}$ & $\begin{array}{l}\text { Film/piezoelectric } \\
\text { sensor }\end{array}$ & [65] \\
\hline $\mathrm{CNF}$ & Chitosan & $\begin{array}{c}\text { Having higher piezoelectric response } \\
\text { (7-8 pC/N) for solvent cast films } \\
\text { based on CNF rather than } \mathrm{CNC}, \\
\text { chitosan and their blends } \\
\text { Enhancing the flexibility by adding } \\
\text { chitosan. }\end{array}$ & $\begin{array}{l}\text { Film/piezoelectric } \\
\text { sensor }\end{array}$ & [66] \\
\hline $\mathrm{CNF}$ & Polyaniline & $\begin{array}{c}\text { Showing proper conductivity because } \\
\text { of the formation of continuous PANI } \\
\text { coating over the CNFs. } \\
\text { Attenuation of incoming microwave } \\
\text { radiations via an absorption } \\
\text { mechanism. }\end{array}$ & $\begin{array}{l}\text { Composite nanopa- } \\
\text { per/supercapacitors, } \\
\text { commercial electronic } \\
\text { gadgets }\end{array}$ & [67] \\
\hline $\mathrm{CNF}$ & $\mathrm{Fe}_{3} \mathrm{O}_{4}$ nanoparticles & $\begin{array}{l}\text { Reduction in the mechanical } \\
\text { properties due to the lower aspect } \\
\text { ratio of added nanoparticles } \\
\text { Avoiding the iron core in } \\
\text { loudspeakers. }\end{array}$ & Membrane/loudspeakers & [68] \\
\hline $\mathrm{CNF}$ & Polyethylene & $\begin{array}{l}\text { Significant improvement in the } \\
\text { cycling stability and safety of batteries } \\
\text { based on Li metal } \\
\text { Enhancement of wettability and } \\
\text { thermal stability without shrinkage. }\end{array}$ & $\begin{array}{c}\text { A tri-layer } \\
\mathrm{CNFs} / \mathrm{PE} / \mathrm{CNFs} \\
\text { separator for lithium } \\
\text { batteries }\end{array}$ & [69] \\
\hline $\mathrm{CNC}$ & $\begin{array}{l}\text { Chitosan, antibacterial } \\
\text { agent }\end{array}$ & $\begin{array}{l}\text { Reduction in air permeability by } \\
\text { adding } 8 \% \text { CNC } \\
\text { Enhancing paper resistance towards } \\
\text { different microorganisms, specifically } \\
\text { those causing food poisoning. }\end{array}$ & $\begin{array}{l}\text { Paper sheet/food } \\
\text { packaging }\end{array}$ & [70] \\
\hline $\mathrm{CNC}$ & - & $\begin{array}{l}\text { Color variation by exposure to } \\
\mathrm{NH}_{3} . \mathrm{H}_{2} \mathrm{O}, \mathrm{H}_{2} \mathrm{O}, \mathrm{HCl} \text {, acetic acid. }\end{array}$ & $\begin{array}{l}\text { Coating/chemical } \\
\text { sensors }\end{array}$ & [71] \\
\hline $\mathrm{CNC}$ & $\begin{array}{l}\text { Fluorophore tagged } \\
\text { polystyrene latex bead }\end{array}$ & $\begin{array}{c}\text { Having } \log _{10} \text { reduction value }(\mathrm{LRV}) \geq \\
6.3 .\end{array}$ & $\begin{array}{l}\text { Membrane/removing } \\
\text { of influenza virus }\end{array}$ & [72] \\
\hline $\begin{array}{l}\text { CNC functionalized } \\
\text { with aldehyde groups }\end{array}$ & - & $\begin{array}{l}\text { Proper adsorption of nisin and } \\
\text { lysozyme onto the CNC. }\end{array}$ & $\begin{array}{c}\text { Adsorption of } \\
\text { lysozyme and nisin }\end{array}$ & [73] \\
\hline
\end{tabular}


Table 3. Cont.

\begin{tabular}{|c|c|c|c|c|}
\hline Type of Nanocellulose & Other Components & Results & $\begin{array}{c}\text { Product } \\
\text { Forms/Application }\end{array}$ & Ref. \\
\hline Carboxylated CNC & $\begin{array}{l}\text { Poly }(\mathrm{N}- \\
\text { isopropylacrylamide })\end{array}$ & $\begin{array}{l}\text { Exhibition the } \mathrm{pH} \text { - and temperature- } \\
\text { sensitivity } \\
\text { Improving the stiffness by increasing } \\
\text { the amount of } \mathrm{CNC}\end{array}$ & Hydrogel/biosensors & [74] \\
\hline $\mathrm{BC}$ & Chitosan & $\begin{array}{c}\text { Ability to retain moisture content for } \\
\text { an extensive period without } \\
\text { dehydration } \\
\text { Showing a remarkable growth } \\
\text { inhibition for Escherichia coli and } \\
\text { Staphylococcus aureus } \\
\text { Decreasing the tensile strength and } \\
\text { elongation at break Increasing the } \\
\text { Young modulus compared to BC } \\
\text { No toxic effects on animal cells }\end{array}$ & $\begin{array}{l}\text { Membrane/wound } \\
\text { healing }\end{array}$ & {$[75,76]$} \\
\hline $\mathrm{BC}$ & PVA & $\begin{array}{c}\text { Giving a broad range of mechanical } \\
\text { properties, including a high degree of } \\
\text { anisotropy }\end{array}$ & $\begin{array}{l}\text { Nanocomposites/Devices } \\
\text { for replacing } \\
\text { cardiovascular and } \\
\text { other connective tissues }\end{array}$ & [77] \\
\hline $\mathrm{BC}$ & gelatin & $\begin{array}{l}\text { Having a proper interconnected pore } \\
\text { network structure } \\
\text { Improving thermal stability } \\
\text { Having much better biocompatibility } \\
\text { than pure BC by cell culture test }\end{array}$ & $\begin{array}{l}\text { Composites/Wound } \\
\text { dressing, } \\
\text { tissue-engineering } \\
\text { scaffolds }\end{array}$ & [78] \\
\hline $\mathrm{BC}$ & Platinum nanoparticle & $\begin{array}{l}\text { Increasing thermal stability } \\
\text { Showing high electro-catalytic activity. }\end{array}$ & $\begin{array}{l}\text { Membrane/fuel cell } \\
\text { and biosensor }\end{array}$ & [79] \\
\hline Bacterial nano-cellulose & GO, Palladium & $\begin{array}{l}\text { Showing highly efficient methylene } \\
\text { orange degradation during filtration } \\
\text { Removing contaminants including } \\
\text { methylene blue, rhodamine }\end{array}$ & Membrane/ultrafiltration & [80] \\
\hline
\end{tabular}

\section{Life Cycle Assessment (LCA) of Cellulose}

LCA is a useful tool for assessing environmental impacts related to the extraction of raw material, manufacturing, use of final products, and disposal. In other words, all the stages from the fabrication of products by using raw materials (cradle) to end-of-life (EOL) disposal methods of final products (grave) constitute LCA. Since cellulose-derived monomers and their derivatives, the first and second groups, are converted to chemicals and other polymers, their LCA is not performed. Therefore, the LCA of nanocelluloses and their products will be elaborated on in the subsequent sections. Due to some challenges such as data unavailability, inconsideration towards end-of-life treatments, and limitations related to the lab-scale processes, there are only a few LCA studies related to cellulose products, i.e., cradle-to-grave. Therefore, we characterized our LCA studies into two categories of cradle-to-gate and cradle-to-grave; their detailed information is shown in Table 4. Figure 5 shows a schematic of all the stages of the life cycle of nanocellulose products. The LCA for each form of cellulose can be investigated in terms of cumulative energy demand (CED), ozone depletion (kg CFC-11 equivalents), terrestrial acidification (TA, $\mathrm{kg}$ $\mathrm{SO}_{2}$ equivalents), eutrophication ( $\mathrm{kg}$ of phosphorus equivalent for freshwater, $\mathrm{kg}$ nitrogen equivalent for marine), water depletion (WD, cubic meters), human toxicity (HT, kg of 1,4-dichlorobenzene equivalent) and fossil fuel depletion ( $\mathrm{kg}$ Oil equivalents), and climate change (CC) in the following sections. The evaluation of climate change in the life cycle, which is related to GHG emissions, resource depletion, global warming potential (GWP, $\mathrm{kg} \mathrm{CO}$ equivalents), and waste generation, is done to develop low-carbon materials. The 
main tools that are used for assessing the environmental impacts include CED (SimaPro v1.08 software, PRé Sustainability, Amersfoort, The Netherlands), International Panel on Climate Change (IPCC) (World Meteorological Organization, Geneva, Switzerland) with a time frame of 100 years (IPCC7 GWP 100a v1.02), Eco-Indicator-99 (PRé Susteinability, Amersfoort, The Netherlands) (EI99, SimaPro v2.08 for human health, ecosystem quality and resources), CML2001 (the Institute of Environmental Sciences, Leiden, The Netherlands) and ReCiPe (endpoint or midpoint for different parameters) (RIVM, Utrecht, The Netherlands). In the ReCiPe method, the life cycle inventory results transform to a limited number of indicator scores, where each indicator score illustrates the relative severity of an environmental impact category. Eco-indicator 99 identifies 11 environmental impact categories into three environmental damages endpoints, including human health, ecosystem quality, and resources.

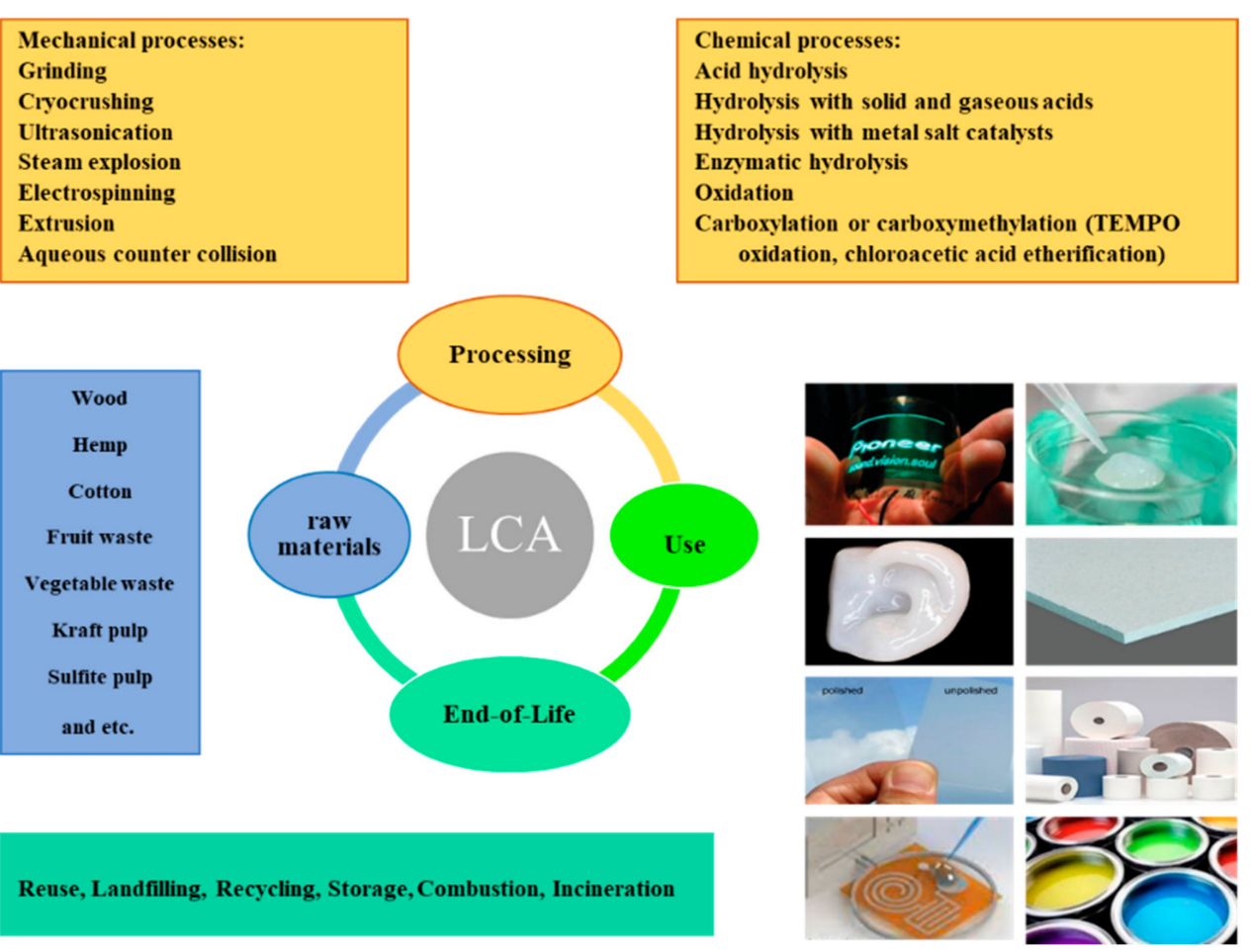

Figure 5. The life cycle of nanocellulose products, including raw materials, processing, use, and end-of-life stages. 
Table 4. A summary of LCA findings of nanocellulose products, including cumulative energy demand and climate change from cradle-to-gate.

\begin{tabular}{|c|c|c|c|c|c|c|c|c|c|}
\hline $\begin{array}{l}\text { Researchers/Type } \\
\text { of Cellulose }\end{array}$ & Production Method & CED Value & $\begin{array}{l}\mathrm{GWP}(\mathrm{kg} \\
\left.\mathrm{CO}_{2} \mathrm{eq}\right)\end{array}$ & $\begin{array}{l}\mathrm{ME} / \mathrm{FE}(\mathrm{kg} \mathrm{N} \\
\text { eq/kg p eq) }\end{array}$ & $\mathrm{TA}\left(\mathrm{kg} \mathrm{SO}_{2} \mathrm{eq}\right)$ & $\begin{array}{l}\text { Fossil Fuel } \\
\text { Depletion } \\
\text { (kg Oil eq) }\end{array}$ & $\begin{array}{l}\text { Human } \\
\text { Toxicity } \\
\text { (kg 1,4-DB } \\
\text { eq) }\end{array}$ & $\begin{array}{l}\text { WD }(\mathbf{k g} \\
\text { or }^{3} \\
\left.\mathrm{H}_{2} \mathrm{O}\right)\end{array}$ & Key Assumption Made \\
\hline \multirow{2}{*}{$\begin{array}{l}\text { Hohenthal } \\
\text { et al./CNF [81] }\end{array}$} & Enzymatic + HPH & - & $1.2-3.1$ & $0.015-0.016$ & $0.008-0.045$ & $0.3-0.75$ & - & 50 & \multirow{2}{*}{$\begin{array}{l}\text { Enzymatic pretreatment has more yield and } \\
\text { lower wastewater. } \\
\text { Energy consumption of the TEMPO oxidation } \\
\text { reaction is more in that process. }\end{array}$} \\
\hline & $\begin{array}{c}\text { TEMPO oxidationn }+ \\
\text { mechanical refinement }\end{array}$ & - & $0.75-1.0$ & $0.014-0.015$ & $0.0045-0.005$ & $0.20-0.25$ & - & 120 & \\
\hline \multirow{4}{*}{ Li et al./CMF [5] } & $\begin{array}{l}\text { TEMPO oxidation } \\
+ \text { Sonication + Centrifuge } \\
\text { purifying (TOSO) }\end{array}$ & $145.9 \mathrm{MJ}$ & $\begin{array}{l}980 \text { (per kg } \\
\text { NC) }\end{array}$ & - & - & - & - & - & \multirow{4}{*}{$\begin{array}{l}\text { Weight loss does not have a significant } \\
\text { influence on LCA results. } \\
\text { Both chemical modification processes (TO, } \\
\text { CE) create similar anionic surfaces. } \\
\text { The products of two mechanical } \\
\text { disintegration processes (SO, HO) are the } \\
\text { same. } \\
\text { The batch processing capacity ratio of the HO } \\
\text { process to the CE process is assumed three. } \\
\text { Washing does not influence four different } \\
\text { fabrication routes. } \\
\text { Energy recovery of the } \\
\text { incineration/combustion process was not } \\
\text { considered because of complexity. } \\
\text { Solvent evaporation was considered } \\
\text { negligible. }\end{array}$} \\
\hline & $\begin{array}{c}\text { TEMPO oxidation }+ \\
\text { Homogenization (TOHO) }\end{array}$ & $34.7 \mathrm{MJ}$ & $\begin{array}{c}190 \text { (per kg } \\
\text { NC) }\end{array}$ & - & - & - & - & - & \\
\hline & $\begin{array}{c}\text { Chloroacetic acid } \\
\text { etherification }+ \text { Sonication }+ \\
\text { Centrifuge purifying (CESO) }\end{array}$ & 176.1 MJ & $\begin{array}{l}1160 \text { (per kg } \\
\text { NC) }\end{array}$ & - & - & - & - & - & \\
\hline & $\begin{array}{c}\text { Chloroacetic acid } \\
\text { etherification }+ \\
\text { Homogenization }(\mathrm{CEHO})\end{array}$ & $64.9 \mathrm{MJ}$ & $\begin{array}{l}360 \text { (per kg } \\
\mathrm{NC} \text { ) }\end{array}$ & - & - & - & - & - & \\
\hline \multirow{3}{*}{$\begin{array}{l}\text { Piccinno } \\
\text { et al./CNF [82] }\end{array}$} & $\begin{array}{l}\text { MFC liberated (Enzymatic }+ \\
\text { homogenization) + Coating } \\
\text { MFC with GripX + Wet } \\
\text { spinning by adding Sodium } \\
\text { Alginate (route 1a) }\end{array}$ & \multirow{3}{*}{$\begin{array}{l}32.2 \mathrm{MJ} \text { for } \\
\text { production } \\
\text { of } 10 \mathrm{gr} \\
\text { MFC }\end{array}$} & \multirow{3}{*}{$\begin{array}{c}\text { 1.5-1.6 (10 g of } \\
\text { MFC) }\end{array}$} & - & - & - & - & $\begin{array}{l}(0.201 \text { for } \\
\text { MFC } \\
\text { liberation }) \\
0.2531 / \mathrm{gr}\end{array}$ & \multirow{3}{*}{$\begin{array}{l}\text { All processes are performed in one place } \\
\text { because of the lack of transport between the } \\
\text { various partners. }\end{array}$} \\
\hline & $\begin{array}{c}\text { MFC liberated (Enzymatic + } \\
\text { homogenization) + Wet } \\
\text { spinning by adding Sodium } \\
\text { Alginate (without coating) } \\
\text { (route } 1 \mathrm{~b} \text { ) }\end{array}$ & & & - & - & - & - & $\begin{array}{l}(0.201 \text { for } \\
\text { MFC } \\
\text { liberation }) \\
0.2551 / \mathrm{g}\end{array}$ & \\
\hline & $\begin{array}{c}\text { MFC liberated (Enzymatic + } \\
\text { homogenization) }+ \\
\text { electrospinning by adding } \\
\text { PEO as a carrier polymer } \\
\text { (route 2) }\end{array}$ & & & - & - & - & - & $\begin{array}{l}(0.201 \text { for } \\
\text { MFC } \\
\text { liberation }) \\
0.2051 / g\end{array}$ & \\
\hline $\begin{array}{c}\text { Piccinno } \\
\text { et al./CNF [83] }\end{array}$ & & - & - & - & - & - & - & - & - \\
\hline
\end{tabular}


Table 4. Cont.

\begin{tabular}{|c|c|c|c|c|c|c|c|c|c|}
\hline $\begin{array}{l}\text { Researchers/Type } \\
\text { of Cellulose }\end{array}$ & Production Method & CED Value & $\begin{array}{l}\mathrm{GWP}(\mathrm{kg} \\
\mathrm{CO}_{2} \text { eq) }\end{array}$ & $\begin{array}{l}\mathrm{ME} / \mathrm{FE}(\mathrm{kg} \mathrm{N} \\
\text { eq/kg p eq) }\end{array}$ & $\mathrm{TA}\left(\mathrm{kg} \mathrm{SO}_{2} \mathrm{eq}\right)$ & $\begin{array}{l}\text { Fossil Fuel } \\
\text { Depletion } \\
\text { (kg Oil eq) }\end{array}$ & $\begin{array}{l}\text { Human } \\
\text { Toxicity } \\
\text { (kg 1,4-DB } \\
\text { eq) }\end{array}$ & $\begin{array}{l}\mathrm{WD}(\mathrm{kg} \\
\text { or }^{3} \\
\left.\mathrm{H}_{2} \mathrm{O}\right)\end{array}$ & Key Assumption Made \\
\hline \multirow{3}{*}{$\begin{array}{c}\text { Arvidsson } \\
\text { et al./CNF [84] }\end{array}$} & $\begin{array}{l}\text { Enzymatic pretreatment+ } \\
\text { microfluidization }\end{array}$ & $87 \mathrm{MJ} / \mathrm{kg}$ & 0.79 & - & 0.0078 & - & - & 240 & \multirow{3}{*}{$\begin{array}{l}\text { Neglecting the microbicide input due to low } \\
\text { mass input toward produced CNF. } \\
\text { The contribution of heat losses to the overall } \\
\text { CED is neglected. }\end{array}$} \\
\hline & $\begin{array}{c}\text { Carboxymethylation } \\
\text { pretreatment }+ \\
\text { microfluidization }\end{array}$ & $1800 \mathrm{MJ} / \mathrm{kg}$ & 99 & - & 0.18 & - & - & 1000 & \\
\hline & $\begin{array}{c}\text { Without pretreatment }+ \\
\text { homogenization treatment }\end{array}$ & $240 \mathrm{MJ} / \mathrm{kg}$ & 1.2 & - & 0.0069 & - & - & 130 & \\
\hline \multirow{2}{*}{$\begin{array}{l}\text { Figueiredo } \\
\text { et al./CNC [85] }\end{array}$} & EUC system & $\begin{array}{l}15.943 \mathrm{MJ} \\
\text { for the } \\
\text { extraction of } \\
\text { raw } \\
\text { materials }\end{array}$ & 1.086412 & $0.000320 / 0.000134$ & - & - & 0.291122 & $131 \mathrm{~L} / \mathrm{g}$ & \multirow{2}{*}{$\begin{array}{l}\text { Transportation of coconut husks was not } \\
\text { considered due to the installation of these } \\
\text { units in the vicinity of companies extracting } \\
\text { coconut water. } \\
\text { The transportation of fibers and chemicals are } \\
\text { neglected because of lab-scale processes. }\end{array}$} \\
\hline & EC system & $\begin{array}{l}1.8 \mathrm{MJ} \text { for } \\
\text { the } \\
\text { extraction of } \\
\text { raw } \\
\text { materials }\end{array}$ & 0.122171 & $0.000065 / 0.000024$ & - & - & 0.034797 & $138 \mathrm{~L} / \mathrm{g}$ & \\
\hline \multirow{3}{*}{$\begin{array}{l}\text { Nascimento } \\
\text { et al./CNC [86,87] }\end{array}$} & $\begin{array}{l}\text { Extraction of CNC with } \\
\text { dilute sulfuric acid (CNH1) }\end{array}$ & - & - & - & - & - & - & - & \multirow{3}{*}{$\begin{array}{l}\text { Lignin was burned and used as a power } \\
\text { source for cellulose nanocrystal extraction. }\end{array}$} \\
\hline & $\begin{array}{l}\text { Extraction of CNC with } \\
\text { ammonium persulfate } \\
\text { (CNO) }\end{array}$ & - & - & - & - & - & - & - & \\
\hline & $\begin{array}{l}\text { Extraction of } \mathrm{CNC} \text { with high } \\
\text { powered ultrasound (CNU) }\end{array}$ & - & 0.207 & $\begin{array}{c}5.68 \times \\
10^{-5} / 3.03 \times \\
10^{-5}\end{array}$ & 0.00045 & - & 0.0477 & 0.0023 & \\
\hline
\end{tabular}


Table 4. Cont.

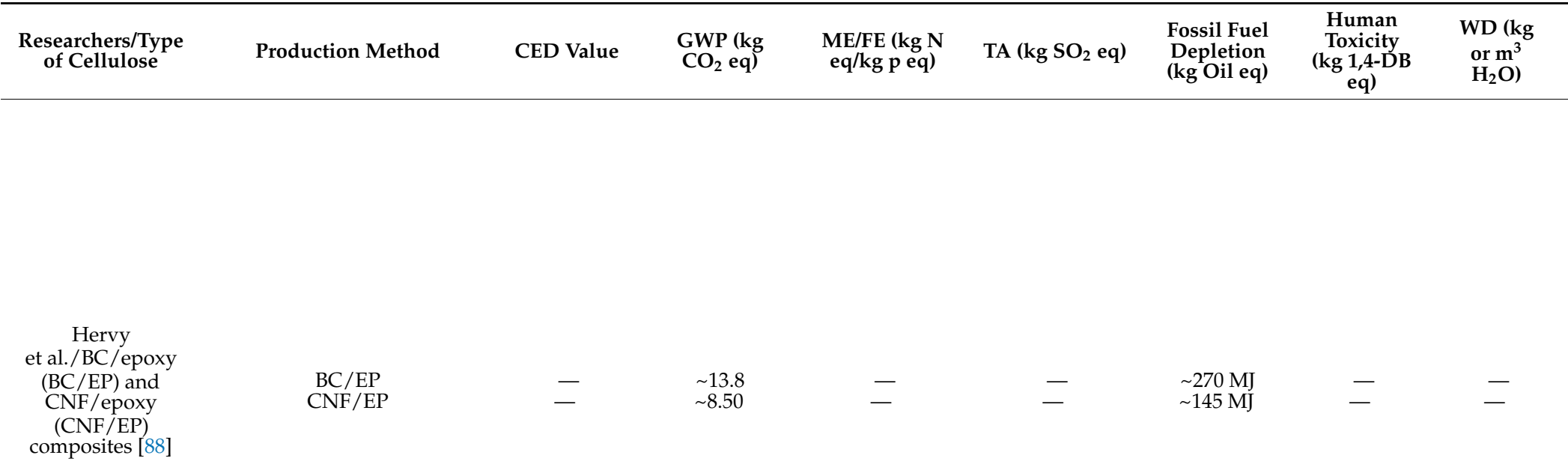
$\mathrm{BC}$ is produced by A.xylinum under certain
conditions, which are specified in the

reference [88].
Purification of BC also was performed in a specific state.

The influence of additional epoxy resin

during the process on the LCA results was not significant.

Materials and energy losses during the processing of the epoxy/BC and CNF

composites were assumed to be negligible.

The environmental impacts related to

transportation were disregarded.

The energy requirement for fibrillating kraft pulp to CNF was determined according to the work of Josset et al. [89]. work of Josset et al. [89]. tho papers.

The efficiency of all electrical appliances was The durability of to be $100 \%$.

containing BC and CNF PLA and GF/PP

containing $\mathrm{BC}$ and $\mathrm{CNF}$, $\mathrm{CA}$, and GF/PP

were considered same [88] 


\section{LCA from Cradle-To-Gate}

Hohenthal et al. evaluated the environmental impact of CNF for the first time. Their study was based on the cradle-to-gate LCA for the production of one-ton CNF using sulfite pulp as raw material and three different processing routes shown in Table 4 and two laboratories and one pilot-scale study. LCA was performed using the ReCiPe method and included GWP, eutrophication, TA, water depletion, and fossil fuel depletion (Table 4) [81]. Besides, a difference in electricity consumption between chemical processes was investigated. Table 4 shows that there is a considerable difference in wastewater between three different processing routes. Moreover, enzymatic pre-treatment has more yield and consumes more energy amongst chemical pre-treatment processes. In contrast, the TEMPO oxidation reaction's energy consumption is less than other strategies and has a lower yield.

Li et al. studied the Cradle-to-gate LCA for $10 \mathrm{~g}$ of MFC from kraft pulp as raw materials on a laboratory scale. The fabrication processes included chemical treatment followed by mechanical techniques $[90,91]$. In this regard, chemical pre-treatments included 2,2,6,6-tetramethylpiperidine-1-oxyl (TEMPO) oxidation and chloroacetic acid etherification [92-95]. Additionally, homogenization and sonication processes were selected as mechanical disintegration processes $[90,91,96]$. For samples treated by the sonication process, a centrifuge purifying process was required. Therefore, there were four possible routes of MFC production. CED (with SimaPro v1.08 software) and GWP (IPCC 7 GWP 100a v1.02) were assessed as two important environmental impacts. Furthermore, three main categories of environmental impacts, including human health, ecosystem quality, and resources, were assessed by Eco-Indicator 99 (EI 99, SimaPro v2.08) method and different egalitarian (E), hierarchist $(\mathrm{H})$, and individualist (I) perspectives, which are long, medium, and short time horizon, respectively. The obtained results for CED and GWP are summarized in Table 4 [5]. Generally, they observed that the chloroacetic acid etherification and sonication processes require more energy for chemical and mechanical processes, respectively. Therefore, $\mathrm{TOHO}$ and $\mathrm{CESO}$ processes require a minimum and maximum energy, respectively. Besides, the GWP trend is similar to CED because $\mathrm{CO}_{2}$ is emitted by using fossil fuels. The results of EI 99 show that human health has more importance in short- term perspective, while resources become more important for hierarchist and egalitarian perspectives. It is worth mentioning that ecosystem quality stays the same factor for all three perspectives. Moreover, among different nanocellulose production methods, the TOHO and CESO routes have the lowest and highest environmental impacts in each perspective.

In another study performed by Piccinno et al., the environmental impact for cradle-togate LCA of $1 \mathrm{~g}$ CNF was evaluated. The authors extracted CNF from waste carrot (carrot or carrot pomace) and considered three routes for fabricating CNF in the laboratory (as explained in Table 4). In this study, the impact assessment's different scenarios included GWP, CED, ecosystem quality, human health, and resources by ReCiPe midpoint and endpoint indicators with the hierarchist perspective [82]. The results of ReCiPe endpoint indicators of three routes show that electrospinning has a higher impact on the environment than wet spinning due to the smaller scale, lower yield $(60 \%)$, and mainly the high-energy consumption during this process. In wet spinning (route 1a and 1b), the liberation of MFC was considered as the most energy-consuming stage. A closer look at the MFC liberation stage shows that the enzymatic treatment is the main contributor to environmental impact because a lot of energy is needed for heating and stirring the mixture at $40{ }^{\circ} \mathrm{C}$ for $24 \mathrm{~h}$. Besides, this stage has the highest share of wastewater. On the other hand, according to the results of ReCiPe midpoint indicators for route 1a, the liberation of the MFC has the highest environmental impact. Besides, acetone usage in the solvent exchange and GripX production has a high potential for photochemical oxidant formation and terrestrial ecotoxicity, respectively.

In comparison with the production of $10 \mathrm{~g}$ of MFC, which was studied by Li et al., the total energy consumption for the enzymatic treatment was lower than $\mathrm{HO}$ and $\mathrm{SO}$ processes in Li et al. study because, in the wood pulp production process, chemicals were 
responsible for a significant portion of $C E D$, while in this process, electricity contributes to about $95 \%$ of the CED. About GWP, the impact of the TOHO route $\left(1.9 \mathrm{~kg} \mathrm{CO}_{2}\right.$ eq) was close to the process of this study.

In another study by Piccinno et al. on the impact assessment of CNF, the authors applied the scale-up framework to address the limitations of the lab-scale processes. In this regard, the authors only evaluated the Cradle-to-gate LCA for $1 \mathrm{~kg}$ of spun yarn process with the GripX coating (route 1: MFC liberated (enzymatic + homogenization) + coating MFC with GripX + wet spinning by adding sodium alginate). They examined different systems resulting in several scenarios, including different types of starting materials (carrot, carrot pomace), enzyme deactivation procedures (with heat or with a bleaching agent, $\mathrm{ClO} 2)$, with or without heat, and solvent recovery, solvent exchange, or drying of the acetone. The authors evaluated the LCA of these routes based on depletion of resources, damage to human health, and ecosystem quality by applying the ReCiPe method (endpoint and midpoint) with the hierarchist perspective. The findings related to these scenarios show that: (1) using carrot pomace as a starting material reduces every step, such as transport, (2) using bleaching agent for deactivating the enzymes is preferable than heat deactivation, (3) solvent recovery in producing GripX has a considerable advantage [83].

In another study by Arvidsson et al., Cradle-to-gate LCA for $1 \mathrm{~kg}$ of CNF manufactured by wood pulp was studied by three different production methods (as shown in Table 4). For the manufacture of CNF, four different types of pulp were used, which contain elementary chlorine-free sulfate (ECF), totally chlorine-free sulfate (TCF), unbleached sulfate, and chlorine-bleached sulfite pulp. The environmental impact was studied in CED, GWP, TA, and WD, using the CED (SimaPro v1.08 software) ReCiPe method. The results of these categories are summarized in Table 4 [84]. According to Table 4, the environmental impact of the carboxymethylation route is significantly higher than other routes. To be more specific, for the carboxymethylation route, CED is higher compared to other routes because of the use of chemicals such as ethanol, isopropanol, and methanol. Besides, the pretreatment stage was the main contributor in GWP, TA, and WD. For the enzymatic route, pulp production has the main share in CED and GWP; while water usage in the washing stage and phosphate production, enzymatic treatment has more impact in WD and TA. The treatment process contributes more CED, WD, and GWP than pulp production for the no pretreatment route. However, the share of pulp production in TA is more considerable than in the treatment process.

In comparison with the study by Li et al., generally, the environmental impacts from the enzymatic and no pretreatment methods are lower than that of the TOHO process, which has the lowest environmental impact in that study.

Figueiredo et al. studied the Cradle-to-gate LCA of $1 \mathrm{~g} \mathrm{CNCs}$ for the first time. The authors produced CNCs through acid hydrolysis from two different raw materials, namely, unripe coconut fibers (EUC process) and white cotton fibers (EC process) on a laboratory scale. Figure $6 \mathrm{a}, \mathrm{b}$ presents the system boundary for EUC and EC processes, respectively. The authors evaluated the environmental impact, including CC, WD, HT, and eutrophication, using the ReCiPe method. In the ReCiPe method, climate change expresses the results according to the IPCC. The obtained values for each parameter are summarized in Table 4. The EUC system considers extra environmental impact than EC system except for WD. To elucidate, water consumption in turbines at hydropower plants to produce energy in the systems is the main contributor to WD. Furthermore, due to copper's use in cables that distribute electricity, the EUC system generates more toxic substances and nutrients, leading to human toxicity and freshwater and marine eutrophication. In the EC system, the production of cotton on farms has a significant share in eutrophication. 


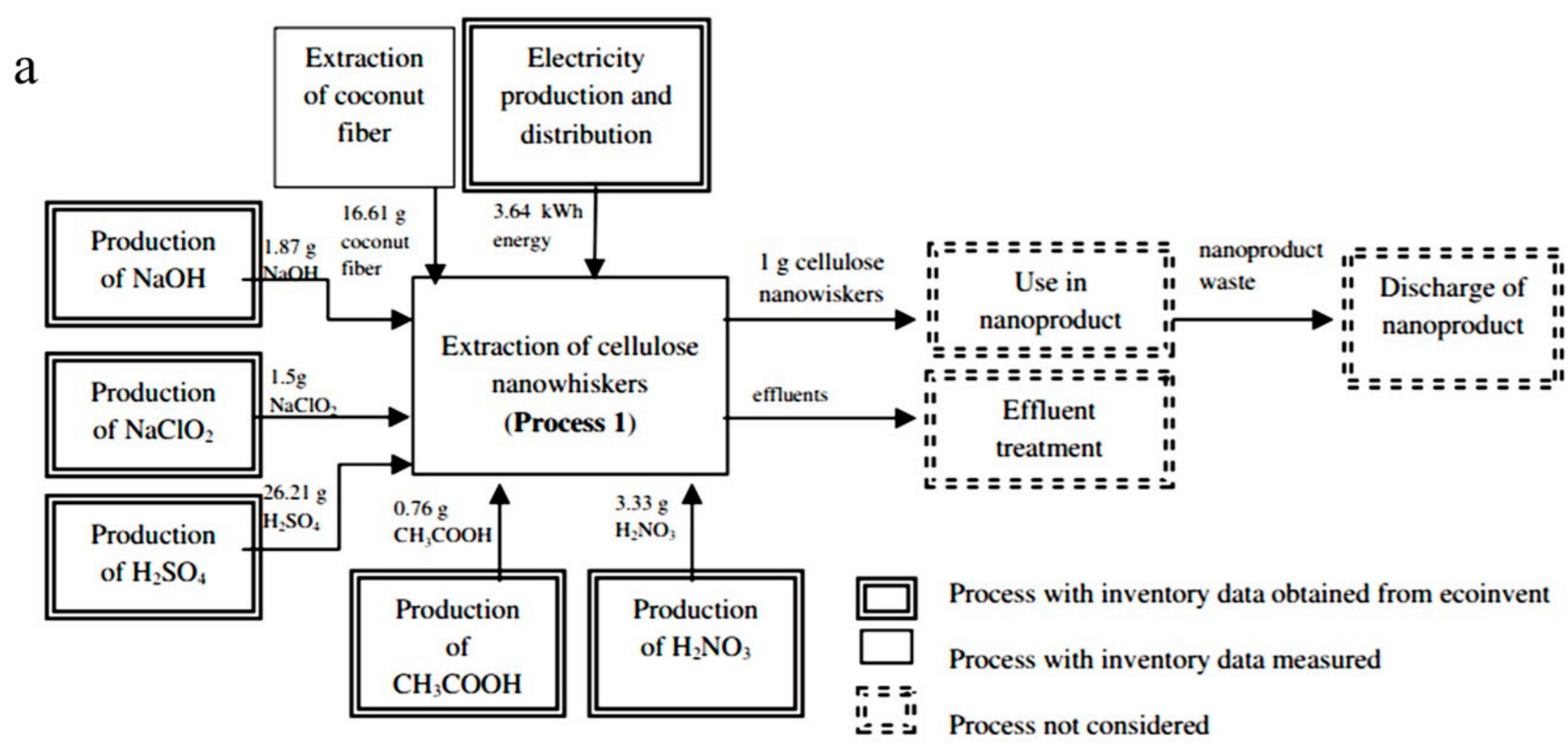

b

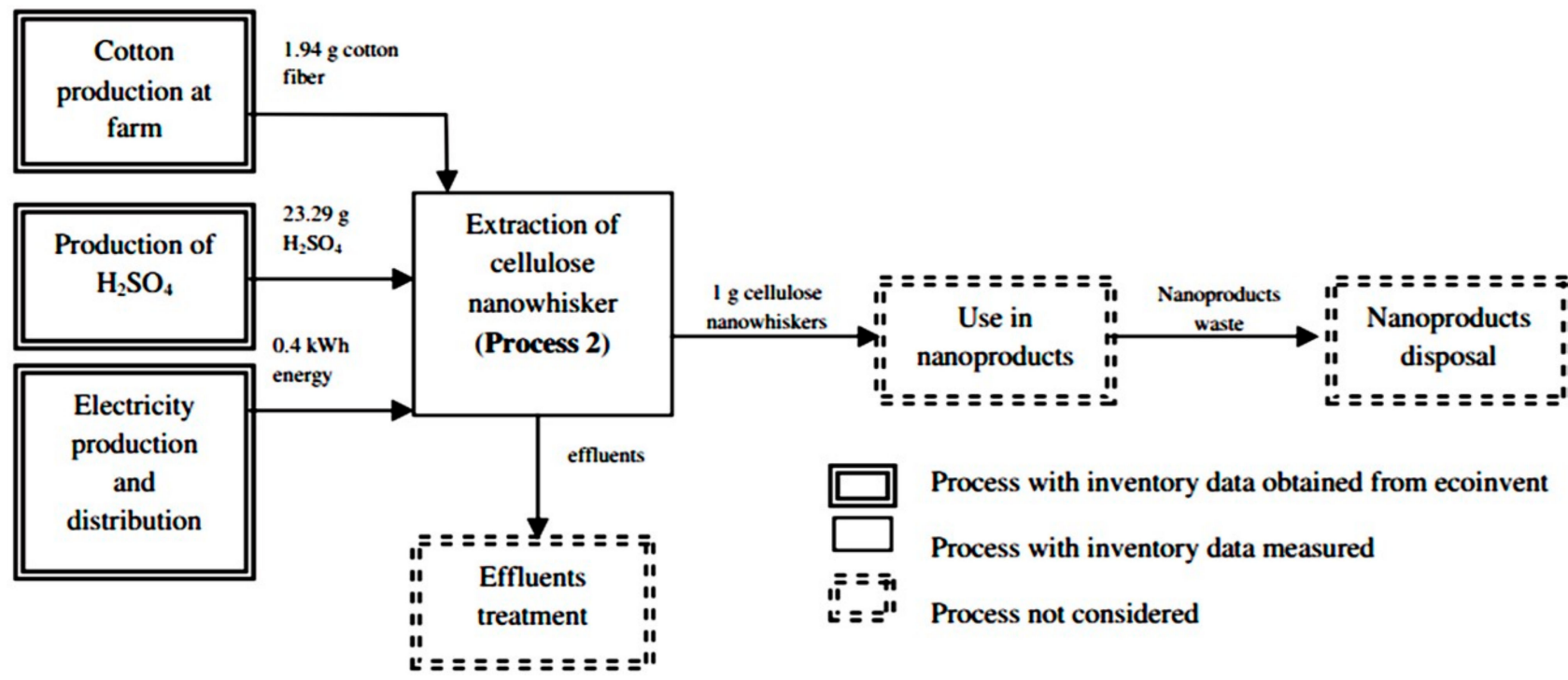

Figure 6. (a) EUC system (raw material: unripe coconut fiber), (b) EC system (raw material: cotton fiber) [85].

Additionally, the energy demanded by two process routes were compared with each other and other nanomaterials such as CNTs and carbon nanofibers. It is observed that the EUC system also demands more energy than the EC system. The extraction process in both systems is the main contributor to energy consumption. Compared to the production of 1 $\mathrm{g}$ carbon nanofibers, the production of $1 \mathrm{~g} \mathrm{CNC}$ in the EC system has a lower impact on $\mathrm{CC}$ and HT, whereas the EUC system is affected at the same level [85]. The energy demand to make $1 \mathrm{~g}$ nanowhiskers in the EC system is lower than $1 \mathrm{~g}$ carbon nanotube and carbon nanofiber.

In another study of $\mathrm{CNC}$ production, Nascimento et al. evaluated the Cradle-to-gate LCA to produce $1 \mathrm{~g}$ of $\mathrm{CNC}$ from four different $\mathrm{CNC}$ extraction methods after extraction of coconut fiber on a lab-scale (as shown in Table 4). These methods were applied for recovering lignin by four other chemicals used to hydrolyze cellulose. Categories consisted of CC, TA, eutrophication (FE and ME), HT and WD were evaluated as environmental impact criteria via the ReCiPe method (at the midpoint level) with a hierarchical version. The results related to these assessments are summarized in Table $4[86,87]$. These results 
show that the CNU route has the lowest resource consumption and emission loads for producing $1 \mathrm{~g} \mathrm{CNC}$. Besides, this route has the highest yield among all the other routes. The usage of a high concentration of $\mathrm{H}_{2} \mathrm{SO}_{4}$ to speed up the hydrolysis of the amorphous domains leads to a decrease in the yield in the $\mathrm{CNH} 2$ method. Moreover, high reaction time, high demand for equipment use, and high selectivity of ammonium persulphate are the main reasons for the lower yield of the CNO method. However, the fabrication of CNC from the $\mathrm{CNU}$ route has more environmental impacts than the fabrication of CNF studied by Arvidsson et al. [84] and Piccinno et al. [83].

\section{LCA from Cradle-to-Grave}

To complete the investigation of environmental impact, it is essential to evaluate all stages from the extraction of raw materials (cradle) to EOL of cellulose products (grave). In this regard, Hervy et al. studied cradle-to-gate and cradle-to-grave LCA of the epoxy/BC and CNF composites for the first time. The authors used PLA and reinforced polypropylene $/ 30 \mathrm{wt} \%$ glass fiber (GF/PP) as benchmark materials for comparison. Figure 7 shows the system boundaries for the epoxy/BC and CNF composites' life cycle, neat PLA, and GF/PP composites. Final products were considered to be used as automobile parts. Depending on the waste density, landfills, incineration to recover energy, and recycling were selected as the end-of-life treatments for the plastic wastes. GWP and abiotic depletion of fossil fuels (ADF) were used to assess the environmental impact via the CML2001 (April 2013 version) method developed by the Centre for Environmental Science in Leiden University.

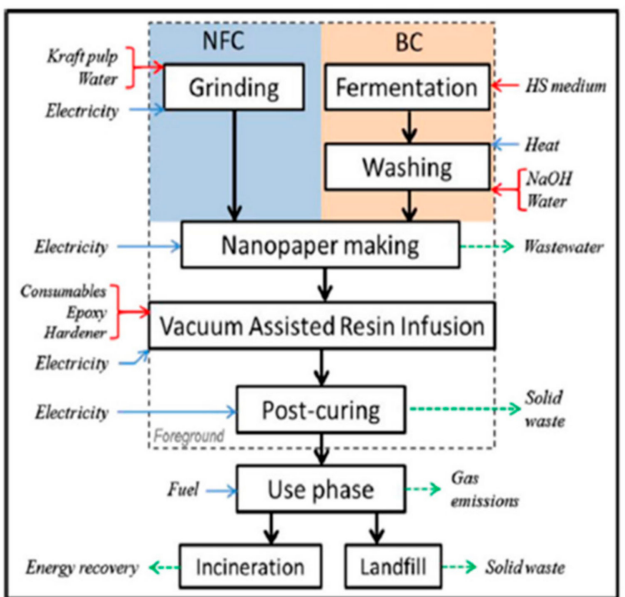

b

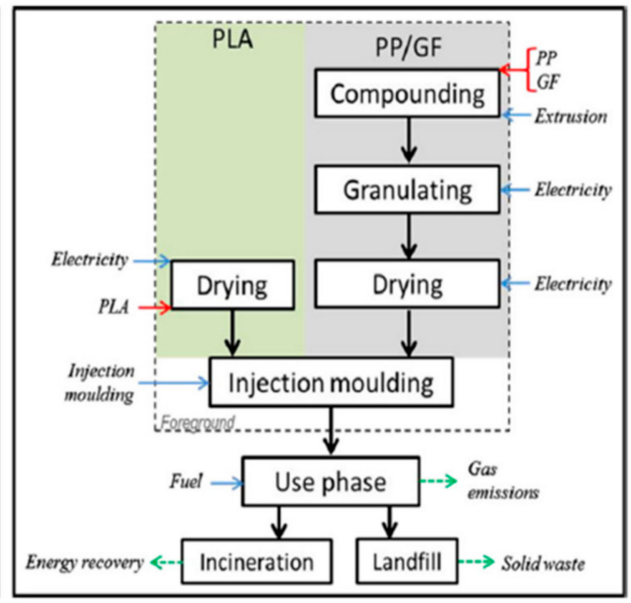

Figure 7. System boundaries for the life cycle of the (a) epoxy composites containing BC and CNF, (b) pure PLA and GF/PP composites. Red arrow: raw material required, blue: energy consumption, green arrow: material and energy wastes [88].

Considering the results in Table 4, for $\mathrm{BC} / \mathrm{EP}$ composites, $\mathrm{ADF}$ was more than pure PLA and GF/PP composites. However, their study showed that the amount of BC/EP composites required were less due to the higher tensile modulus. Besides, $\mathrm{BC} / \mathrm{EP}$ composites have the highest GWP compared with other materials. On the other hand, CNF/EP composites showed the same results compared to pure PLA and GF/PP composites, except that their values were less than $\mathrm{BC} / \mathrm{EP}$ composites. The reason should be the higher amount of CNF needed to reinforce the epoxy.

Generally, although the evaluation of cradle-to-gate LCA of epoxy composites containing $\mathrm{BC}$ and $\mathrm{CNF}$ shows higher environmental impacts than pure PLA and GF/PP, the cradle-to-grave LCA of the composite containing 60 vol.\% nanocellulose was lower than that of the pure PLA and GF/PP composites. To be more specific, in comparison with neat PLA and GF/PP, neat PLA has a higher GWP among all composites. In contrast, GF/PP 
composites have the lowest values. The cause attributed to these results is that the mass required to achieve performance is less for GF/PP composites.

\section{Challenges in Life Cycle Assessments (LCAs) of Cellulose Products}

Studying the life cycle of cellulose products has become important because of greater attention paid towards the development of sustainable and renewable biopolymers. Life cycle assessment can be used as an effective tool for evaluating environmental impacts. However, since only laboratory data are available, there is no accurate assessment that includes all the impacts of cellulose products on different environmental aspects such as air emissions, human health, and waste stream discharges. On the other hand, data unavailability is one of the other limitations of lab-scale processes because they do not account for the end-of-life stage of the cellulose materials. At present, most studies conducted on the environmental impacts are related to the cradle-to-gate LCA $[97,98]$.

In this view, scaling up of the production processes is one of the greatest challenges because, in many cases, laboratory processes are completely different from industrial processes. In the laboratory scale, subsequent steps are linked to each other regardless of material and energy recovery. On the other hand, the simple design of plants and considering the linear scaling factor for scale-up is not reasonable. For example, in Piccinno et al. study, the authors eliminated two CNF production routes due to the limitations of processing techniques. Besides, the authors considered several processes for recovering materials and heat [83].

\section{Specific Strategies for Reduction of Energy Consumption and Development of Low-Carbon Materials}

In the previous section, the LCA of cellulose materials was investigated by various criteria. In every step of the cellulose products' life cycle, there are some issues related to the energy demand and GHG emissions, which should be addressed by technology developers and LCA practitioners. Some of these issues are associated with the stages from the extraction of cellulose to delivery of cellulose products and the use or service stage of cellulose products. There are insufficient findings in many cases, especially regarding the impact of starting material's use on supply chains of other products, characterization of produced by-products and waste streams, and their impacts on supply chains of other products. Moreover, in the cellulose products' end-of-life stage, information about disposal or recycling, the amounts of waste materials, and the release of emissions into the atmosphere are not specified. Considering the issues mentioned earlier, Table 5 shows some suggested strategies related to reducing energy consumption and developing low-carbon materials for future studies. 
Table 5. Suggested strategies for reducing energy demand and development of a low-carbon economy for cellulose products.

\begin{tabular}{|c|c|c|c|}
\hline Step of the LCA & & $\begin{array}{l}\text { trategies for Reduction of Energy } \\
\text { Demand }\end{array}$ & $\begin{array}{l}\text { Strategies for the Development of } \\
\text { Low-Carbon Materials }\end{array}$ \\
\hline Extraction of raw materials & 1. & $\begin{array}{l}\text { Usage of fruit and vegetable wastes } \\
\text { reduces energy consumption [83]. }\end{array}$ & $\begin{array}{l}\text { Usage of fruit and vegetable wastes } \\
\text { reduces environmental impacts [83]. }\end{array}$ \\
\hline Cellulose products manufacturing & $\begin{array}{l}1 . \\
2 . \\
3 . \\
4 .\end{array}$ & $\begin{array}{l}\text { Using better insulation and heat } \\
\text { recovery during the process. } \\
\text { Burning some by-products for } \\
\text { using the generated energy [87]. } \\
\text { Reducing solvent consumption can } \\
\text { decrease energy consumption for } \\
\text { the reaction indirectly. } \\
\text { Reducing the reaction time can } \\
\text { decrease power consumption [99]. }\end{array}$ & 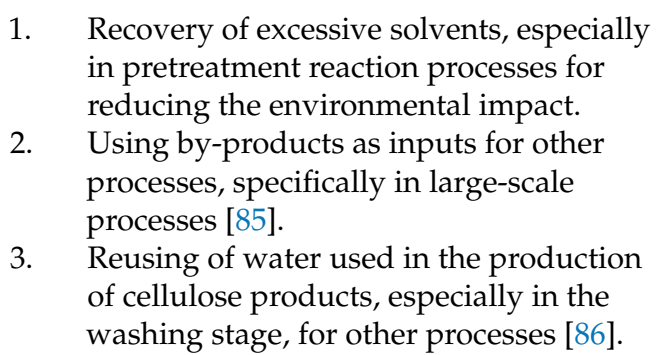 \\
\hline Cellulose products use & & - & $\begin{array}{l}\text { Manufacturing of high-quality products } \\
\text { increases the lifespan and decreases the } \\
\text { environmental impacts. }\end{array}$ \\
\hline Cellulose products end-of-life & & - & $\begin{array}{l}\text { Preventing the burning of wastes as much as } \\
\text { possible due to the emission of toxic gases into } \\
\text { the atmosphere. }\end{array}$ \\
\hline
\end{tabular}

\section{Conclusions}

Considering the increasing consumption of cellulose products in recent decades due to their sustainable and biodegradable properties, this study deals with different aspects of this biopolymer. In this regard, the study initially reviews the properties of different cellulose forms, including cellulose-derived monomers and chemicals, cellulose fibers and their derivatives, and nanocelluloses. Then, some of the effects of these forms on manufactured products and their applications in diverse industries such as packaging, biosensors, and medicine were expressed.

Due to the importance of the impacts of various products on the environment, this study's primary purpose is allocated to investigating the life cycle of cellulose materials and environmental impacts from the extraction of raw materials to the end-of-life of products. According to this, since two forms of cellulose, i.e., cellulose-derived monomers and cellulose derivatives, are converted to other chemicals and biopolymers, in this study only the life cycle of nanocelluloses was evaluated in two cradle-to-gate and cradle-to-grave categories. These assessments were performed with criteria including energy consumption and climate change containing global warming potential, eutrophication, terrestrial acidification, human toxicity, water depletion, and fossil fuel depletion. There are two significant challenges related to the evaluation of the cellulose products' life cycle. The first challenge is data unavailability, especially in the use and disposal stages of nanocellulose products. In other words, many studies in this field assess the environmental impacts of cradle-to-gate. In addition, since most studies were performed on a laboratory scale, the results' accuracy is still unknown. Given that nowadays, economic and climate change issues have received much attention from human societies, reducing the energy-intensive processes and development of low-carbon materials has become especially important. In this regard, in the final section of this study, some strategies related to achieving these goals in different manufacturing stages of the cellulose products have been suggested. 
Author Contributions: Conceptualization, F.F.; E.R.G. and F.M.D.; Writing-Review and Editing, F.F., E.R.G., F.M.D., R.B., and S.R.; Methodology, F.F., E.R.G., and F.M.D.; Writing-Original Draft, F.F. and F.M.D.; Validation, F.F. and F.M.D.; Investigation, F.F. and E.R.G.; Supervision, S.R.; All authors have read and agreed to the published version of the manuscript.

Funding: This research received no external funding.

Institutional Review Board Statement: Not applicable.

Informed Consent Statement: Not applicable.

Data Availability Statement: Data is contained within the article.

Conflicts of Interest: The authors declare no conflict of interest.

\section{References}

1. Nechyporchuk, O.; Belgacem, M.N.; Bras, J. Production of cellulose nanofibrils: A review of recent advances. Ind. Crop. Prod. 2016, 93, 2-25. [CrossRef]

2. La Mantia, F.; Morreale, M. Green composites: A brief review. Compos. Part A Appl. Sci. Manuf. 2011, 42, 579-588. [CrossRef]

3. Rezvani Ghomi, E.; Khosravi, F.; Tahavori, M.A.; Ramakrishna, S. Circular Economy: A Comparison Between the Case of Singapore and France. Mater. Circ. Econ. 2021, 3, 2. [CrossRef]

4. Motaung, T.E.; Linganiso, L.Z. Critical review on agrowaste cellulose applications for biopolymers. Int. J. Plast. Technol. 2018, 22, 185-216. [CrossRef]

5. Li, Q.; McGinnis, S.; Sydnor, C.; Wong, A.; Renneckar, S. Nanocellulose Life Cycle Assessment. ACS Sustain. Chem. Eng. 2013, 1, 919-928. [CrossRef]

6. Mohanty, A.K.; Misra, M.; Drzal, L. Sustainable bio-composites from renewable resources: Opportunities and challenges in the green materials world. J. Polym. Environ. 2002, 10, 19-26. [CrossRef]

7. Zheng, J.; Suh, S. Strategies to reduce the global carbon footprint of plastics. Nat. Clim. Chang. 2019, 9, 374-378. [CrossRef]

8. Hertwich, E. The Carbon Footprint of Material Production Rises to 23\% of Global Greenhouse Gas Emissions. SocArXiv 2019. [CrossRef]

9. Klemm, D.; Philpp, B.; Heinze, T.; Heinze, U.; Wagenknecht, W. Comprehensive Cellulose Chemistr. In Fundamentals and Analytical Methods; Wiley-VCH Verlag GmbH: Weinheim, Germany, 1998; Volume 1.

10. Wang, J.; Tavakoli, J.; Tang, Y. Bacterial cellulose production, properties and applications with different culture methods-A review. Carbohydr. Polym. 2019, 219, 63-76. [CrossRef]

11. Nishiyama, Y. Structure and properties of the cellulose microfibril. J. Wood Sci. 2009, 55, 241-249. [CrossRef]

12. Gardner, D.J.; Oporto, G.S.; Mills, R.; Samir, M.A.S.A. Adhesion and surface issues in cellulose and nanocellulose. J. Adhes. Sci. Technol. 2008, 22, 545-567. [CrossRef]

13. Klemm, D.; Heublein, B.; Fink, H.P.; Bohn, A. Cellulose: Fascinating biopolymer and sustainable raw material. Angew. Chem. Int. Ed. 2005, 44, 3358-3393. [CrossRef] [PubMed]

14. Brown, A.J. XIX-The chemical action of pure cultivations of bacterium aceti. J. Chem. Soc. Trans. 1886, 49, 172-187. [CrossRef]

15. Chirayil, C.J.; Mathew, L.; Thomas, S. Review of recent research in nano cellulose preparation from different lignocellulosic fibers. Rev. Adv. Mater. Sci. 2014, 37, 20-28.

16. Douglass, E.F.; Avci, H.; Boy, R.; Rojas, O.J.; Kotek, R. A review of cellulose and cellulose blends for preparation of bio-derived and conventional membranes, nanostructured thin films, and composites. Polym. Rev. 2018, 58, 102-163. [CrossRef]

17. Das, O.; Hedenqvist, M.S.; Johansson, E.; Olsson, R.T.; Loho, T.A.; Capezza, A.J.; Singh Raman, R.K.; Holder, S. An all-gluten biocomposite: Comparisons with carbon black and pine char composites. Compos. Part. A: Appl. Sci. Manuf. 2019, 120, 42-48. [CrossRef]

18. Das, O.; Loho, T.A.; Capezza, A.J.; Lemrhari, I.; Hedenqvist, M.S. A Novel Way of Adhering PET onto Protein (Wheat Gluten) Plastics to Impart Water Resistance. Coatings 2018, 8, 388. [CrossRef]

19. Siqueira, G.; Bras, J.; Dufresne, A. Cellulosic bionanocomposites: A review of preparation, properties and applications. Polymers 2010, 2, 728-765. [CrossRef]

20. John, M.J.; Thomas, S. Biofibres and biocomposites. Carbohydr. Polym. 2008, 71, 343-364. [CrossRef]

21. Qiu, X.; Hu, S. "Smart" materials based on cellulose: A review of the preparations, properties, and applications. Materials 2013, 6, 738-781. [CrossRef]

22. Kholgh Eshkalak, S.; Rezvani Ghomi, E.; Dai, Y.; Choudhury, D.; Ramakrishna, S. The role of three-dimensional printing in healthcare and medicine. Mater. Des. 2020, 194, 108940. [CrossRef]

23. Rezvani Ghomi, E.; Khosravi, F.; Neisiany, R.E.; Singh, S.; Ramakrishna, S. Future of additive manufacturing in healthcare. Curr. Opin. Biomed. Eng. 2021, 17, 100255. [CrossRef]

24. Shaghaleh, H.; Xu, X.; Wang, S. Current progress in production of biopolymeric materials based on cellulose, cellulose nanofibers, and cellulose derivatives. RSC Adv. 2018, 8, 825-842. [CrossRef] 
25. Lin, Y.; Tanaka, S. Ethanol fermentation from biomass resources: Current state and prospects. Appl. Microbiol. Biotechnol. 2006, 69, 627-642. [CrossRef]

26. Zhang, Y.; Chen, E.Y. Polymerization of Nonfood Biomass-Derived Monomers to Sustainable Polymers. In Selective Catalysis for Renewable Feedstocks and Chemicals; Springer International Publishing: Cham, Switzerland, 2014; pp. 185-227.

27. Li, J.; Soares, H.S.; Moulijn, J.A.; Makkee, M. Simultaneous hydrolysis and hydrogenation of cellobiose to sorbitol in molten salt hydrate media. Catal. Sci. Technol. 2013, 3, 1565-1572. [CrossRef]

28. Fan, Y.; Zhou, C.; Zhu, X. Selective catalysis of lactic acid to produce commodity chemicals. Catal. Rev. 2009, 51, 293-324. [CrossRef]

29. Robert, J.L.; Aubrecht, K.B. Ring-opening polymerization of lactide to form a biodegradable polymer. J. Chem. Educ. 2008, 85, 258. [CrossRef]

30. Belgacem, M.N.; Gandini, A. Monomers, Polymers and Composites from Renewable Resources; Elsevier: Amsterdam, The Netherlands, 2011.

31. Rose, M.; Palkovits, R. Cellulose-Based Sustainable Polymers: State of the Art and Future Trends. Macromol. Rapid Commun. 2011, 32, 1299-1311. [CrossRef]

32. Keenan, T.M.; Nakas, J.P.; Tanenbaum, S.W. Polyhydroxyalkanoate copolymers from forest biomass. J. Ind. Microbiol. Biotechnol. 2006, 33, 616. [CrossRef]

33. Manzer, L.E. Catalytic synthesis of $\alpha$-methylene- $\gamma$-valerolactone: A biomass-derived acrylic monomer. Appl. Catal. A Gen. 2004, 272, 249-256. [CrossRef]

34. Manzer, L.E. Biomass Derivatives: A Sustainable Source of Chemicals. In Feedstocks for the Future; American Chemical Society: Washington, DC, USA, 2006; Volume 921, pp. 40-51.

35. Kargarzadeh, H.; Mariano, M.; Gopakumar, D.; Ahmad, I.; Thomas, S.; Dufresne, A.; Huang, J.; Lin, N. Advances in cellulose nanomaterials. Cellulose 2018, 25, 2151-2189. [CrossRef]

36. Fakirov, S.; Bhattacharyya, D. Engineering Biopolymers: Homopolymers, Blends, and Composites; Carl Hanser Verlag GmbH Co KG: Munich, Germany, 2015.

37. Ashori, A. Wood-plastic composites as promising green-composites for automotive industries! Bioresour. Technol. 2008, 99, 4661-4667. [CrossRef]

38. Alemdar, A.; Sain, M. Isolation and characterization of nanofibers from agricultural residues-Wheat straw and soy hulls. Bioresour. Technol. 2008, 99, 1664-1671. [CrossRef]

39. Huber, T.; Müssig, J.; Curnow, O.; Pang, S.; Bickerton, S.; Staiger, M.P. A critical review of all-cellulose composites. J. Mater. Sci. 2012, 47, 1171-1186. [CrossRef]

40. Li, Q.; Zhou, D.; Zhang, P.; Man, P.; Tian, Z.; Li, Y.; Ai, S. The BiOBr/regenerated cellulose composite film as a green catalyst for light degradation of phenol. Colloids Surf. A Physicochem. Eng. Asp. 2016, 501, 132-137. [CrossRef]

41. Liu, X.; Zhang, T.; Pang, K.; Duan, Y.; Zhang, J. Graphene oxide/cellulose composite films with enhanced UV-shielding and mechanical properties prepared in $\mathrm{NaOH}$ /urea aqueous solution. RSC Adv. 2016, 6, 73358-73364. [CrossRef]

42. Qi, H.; Liu, J.; Gao, S.; Mäder, E. Multifunctional films composed of carbon nanotubes and cellulose regenerated from alkaline-urea solution. J. Mater. Chem. A 2013, 1, 2161-2168. [CrossRef]

43. Maria, K.H.; Mieno, T. Production and properties of carbon nanotube/cellulose composite paper. J. Nanomater. $2017,2017$. [CrossRef]

44. Azzaoui, K.; Lamhamdi, A.; Mejdoubi, E.M.; Berrabah, M.; Hammouti, B.; Elidrissi, A.; Fouda, M.M.; Al-Deyab, S.S. Synthesis and characterization of composite based on cellulose acetate and hydroxyapatite application to the absorption of harmful substances. Carbohydr. Polym. 2014, 111, 41-46. [CrossRef]

45. Mulinari, D.R.; Voorwald, H.J.; Cioffi, M.O.; da Silva, M.L. Cellulose fiber-reinforced high-density polyethylene compositesMechanical and thermal properties. J. Compos. Mater. 2017, 51, 1807-1815. [CrossRef]

46. Lei, Y.; Qian, X.; Shen, J.; An, X. Integrated reductive/adsorptive detoxification of Cr (VI)-contaminated water by polypyrrole/cellulose fiber composite. Ind. Eng. Chem. Res. 2012, 51, 10408-10415. [CrossRef]

47. Anna, P.; Zimonyi, E.; Marton, A.; Szep, A.; Matkó, S.; Keszei, S.; Bertalan, G.; Marosi, G. Surface Treated Cellulose Fibres in Flame Retarded PP Composites; Macromolecular Symposia; Wiley Online Library: Hoboken, NJ, USA, 2003; pp. $245-254$.

48. Carrillo, F.; Martín, G.; López-Mesas, M.; Colom, X.; Canavate, J. High modulus regenerated cellulose fiber-reinforced cellulose acetate butyrate biocomposites. J. Compos. Mater. 2011, 45, 1733-1740. [CrossRef]

49. Qi, H.; Cai, J.; Zhang, L.; Kuga, S. Properties of Films Composed of Cellulose Nanowhiskers and a Cellulose Matrix Regenerated from Alkali/Urea Solution. Biomacromolecules 2009, 10, 1597-1602. [CrossRef]

50. Gindl, W.; Schöberl, T.; Keckes, J. Structure and properties of a pulp fibre-reinforced composite with regenerated cellulose matrix. Appl. Phys. A 2006, 83, 19-22. [CrossRef]

51. Duchemin, B.J.C.; Newman, R.H.; Staiger, M.P. Structure-property relationship of all-cellulose composites. Compos. Sci. Technol. 2009, 69, 1225-1230. [CrossRef]

52. Soykeabkaew, N.; Sian, C.; Gea, S.; Nishino, T.; Peijs, T. All-cellulose nanocomposites by surface selective dissolution of bacterial cellulose. Cellulose 2009, 16, 435-444. [CrossRef]

53. Duchemin, B.J.C.; Staiger, M.P.; Tucker, N.; Newman, R.H. Aerocellulose based on all-cellulose composites. J. Appl. Polym. Sci. 2010, 115, 216-221. [CrossRef] 
54. Wang, W.; Liang, T.; Bai, H.; Dong, W.; Liu, X. All cellulose composites based on cellulose diacetate and nanofibrillated cellulose prepared by alkali treatment. Carbohydr. Polym. 2018, 179, 297-304. [CrossRef]

55. Labidi, K.; Korhonen, O.; Zrida, M.; Hamzaoui, A.H.; Budtova, T. All-cellulose composites from alfa and wood fibers. Ind. Crop. Prod. 2019, 127, 135-141. [CrossRef]

56. Habibi, Y.; Lucia, L.A.; Rojas, O.J. Cellulose nanocrystals: Chemistry, self-assembly, and applications. Chem. Rev. 2010, 110, 3479-3500. [CrossRef]

57. Ng, H.-M.; Sin, L.T.; Bee, S.-T.; Tee, T.-T.; Rahmat, A. Review of nanocellulose polymer composite characteristics and challenges. Polym. Plast. Technol. Eng. 2017, 56, 687-731. [CrossRef]

58. Das, O.; Neisiany, R.E.; Capezza, A.J.; Hedenqvist, M.S.; Försth, M.; Xu, Q.; Jiang, L.; Ji, D.; Ramakrishna, S. The need for fully bio-based facemasks to counter coronavirus outbreaks: A perspective. Sci. Total Environ. 2020, 736, 139611. [CrossRef] [PubMed]

59. Jeremic, S.; Djokic, L.; Ajdačić, V.; Božinović, N.; Pavlovic, V.; Manojlović, D.D.; Babu, R.; Senthamaraikannan, R.; Rojas, O.; Opsenica, I.; et al. Production of bacterial nanocellulose (BNC) and its application as a solid support in transition metal catalysed cross-coupling reactions. Int. J. Biol. Macromol. 2019, 129, 351-360. [CrossRef]

60. Zhang, J.; Song, H.; Lin, L.; Zhuang, J.; Pang, C.; Liu, S. Microfibrillated cellulose from bamboo pulp and its properties. Biomass Bioenergy 2012, 39, 78-83. [CrossRef]

61. Dong, S.; Roman, M. Fluorescently Labeled Cellulose Nanocrystals for Bioimaging Applications. J. Am. Chem. Soc. 2007, 129, 13810-13811. [CrossRef]

62. Keshavarzi, N.; Mashayekhy Rad, F.; Mace, A.; Ansari, F.; Akhtar, F.; Nilsson, U.; Berglund, L.; Bergström, L. Nanocellulose-zeolite composite films for odor elimination. ACS Appl. Mater. Interfaces 2015, 7, 14254-14262. [CrossRef]

63. Zhang, C.; Zhou, M.; Liu, S.; Wang, B.; Mao, Z.; Xu, H.; Zhong, Y.; Zhang, L.; Xu, B.; Sui, X. Copper-loaded nanocellulose sponge as a sustainable catalyst for regioselective hydroboration of alkynes. Carbohydr. Polym. 2018, 191, 17-24. [CrossRef]

64. Nechyporchuk, O.; Bordes, R.; Köhnke, T. Wet spinning of flame-retardant cellulosic fibers supported by interfacial complexation of cellulose nanofibrils with silica nanoparticles. ACS Appl. Mater. Interfaces 2017, 9, 39069-39077. [CrossRef]

65. Rajala, S.; Siponkoski, T.; Sarlin, E.; Mettänen, M.; Vuoriluoto, M.; Pammo, A.; Juuti, J.; Rojas, O.J.; Franssila, S.; Tuukkanen, S. Cellulose nanofibril film as a piezoelectric sensor material. ACS Appl. Mater. Interfaces 2016, 8, 15607-15614. [CrossRef]

66. Hänninen, A.; Sarlin, E.; Lyyra, I.; Salpavaara, T.; Kellomäki, M.; Tuukkanen, S. Nanocellulose and chitosan based films as low cost, green piezoelectric materials. Carbohydr. Polym. 2018, 202, 418-424. [CrossRef]

67. Gopakumar, D.A.; Pai, A.R.; Pottathara, Y.B.; Pasquini, D.; Carlos de Morais, L.; Luke, M.; Kalarikkal, N.; Grohens, Y.; Thomas, S. Cellulose nanofiber-based polyaniline flexible papers as sustainable microwave absorbers in the X-band. ACS Appl. Mater. Interfaces 2018, 10, 20032-20043. [CrossRef] [PubMed]

68. Tarrés, Q.; Deltell, A.; Espinach, F.X.; Pèlach, M.À.; Delgado-Aguilar, M.; Mutjé, P. Magnetic bionanocomposites from cellulose nanofibers: Fast, simple and effective production method. Int. J. Biol. Macromol. 2017, 99, 29-36. [CrossRef] [PubMed]

69. Pan, R.; Xu, X.; Sun, R.; Wang, Z.; Lindh, J.; Edström, K.; Strømme, M.; Nyholm, L. Nanocellulose modified polyethylene separators for lithium metal batteries. Small 2018, 14, 1704371. [CrossRef] [PubMed]

70. El-Samahy, M.A.; Mohamed, S.A.; Rehim, M.H.A.; Mohram, M.E. Synthesis of hybrid paper sheets with enhanced air barrier and antimicrobial properties for food packaging. Carbohydr. Polym. 2017, 168, 212-219. [CrossRef]

71. Zhao, Y.; Gao, G.; Liu, D.; Tian, D.; Zhu, Y.; Chang, Y. Vapor sensing with color-tunable multilayered coatings of cellulose nanocrystals. Carbohydr. Polym. 2017, 174, 39-47. [CrossRef]

72. Metreveli, G.; Wågberg, L.; Emmoth, E.; Belák, S.; Strømme, M.; Mihranyan, A. A size-exclusion nanocellulose filter paper for virus removal. Adv. Healthc. Mater. 2014, 3, 1546-1550. [CrossRef]

73. Tavakolian, M.; Okshevsky, M.; van de Ven, T.G.; Tufenkji, N. Developing antibacterial nanocrystalline cellulose using natural antibacterial agents. ACS Appl. Mater. Interfaces 2018, 10, 33827-33838. [CrossRef]

74. Cha, R.; He, Z.; Ni, Y. Preparation and characterization of thermal/pH-sensitive hydrogel from carboxylated nanocrystalline cellulose. Carbohydr. Polym. 2012, 88, 713-718. [CrossRef]

75. Lin, W.-C.; Lien, C.-C.; Yeh, H.-J.; Yu, C.-M.; Hsu, S.-h. Bacterial cellulose and bacterial cellulose-chitosan membranes for wound dressing applications. Carbohydr. Polym. 2013, 94, 603-611. [CrossRef]

76. Rezvani Ghomi, E.; Khalili, S.; Nouri Khorasani, S.; Esmaeely Neisiany, R.; Ramakrishna, S. Wound dressings: Current advances and future directions. J. Appl. Polym. Sci. 2019, 136, 47738. [CrossRef]

77. Millon, L.E.; Guhados, G.; Wan, W. Anisotropic polyvinyl alcohol-Bacterial cellulose nanocomposite for biomedical applications J. Biomed. Mater. Res. Part B Appl. Biomater. 2008, 86, 444-452. [CrossRef] [PubMed]

78. Kim, J.; Cai, Z.; Chen, Y. Biocompatible bacterial cellulose composites for biomedical application. J. Nanotechnol. Eng. Med. 2010, 1, 011006. [CrossRef]

79. Yang, J.; Sun, D.; Li, J.; Yang, X.; Yu, J.; Hao, Q.; Liu, W.; Liu, J.; Zou, Z.; Gu, J. In situ deposition of platinum nanoparticles on bacterial cellulose membranes and evaluation of PEM fuel cell performance. Electrochim. Acta 2009, 54, 6300-6305. [CrossRef]

80. Xu, T.; Jiang, Q.; Ghim, D.; Liu, K.K.; Sun, H.; Derami, H.G.; Wang, Z.; Tadepalli, S.; Jun, Y.S.; Zhang, Q. Catalytically Active Bacterial Nanocellulose-Based Ultrafiltration Membrane. Small 2018, 14, 1704006. [CrossRef] [PubMed] 
81. Hohenthal, C.; Ovaskainen, M.; Bussini, D.; Sadocco, P.; Pajula, T.; Lehtinen, H.; Kautto, J.; Salmenkivi, K. Final assessment of nano enhanced new products. In SUNPAP (Scale-up Nanoparticles in Modern Papermaking), Oct.31, 2012. CTT Technical Research Center of Finland, InnovHub-SSCCP, Poyry Management Consulting Oy. Funded by European Community's 7th Frame Work Programme under Grant Agreement $n^{\circ}$ 228802; VTT Technical Research Centre of Finland: Espoo, Finland, 2012.

82. Piccinno, F.; Hischier, R.; Seeger, S.; Som, C. Life cycle assessment of a new technology to extract, functionalize and orient cellulose nanofibers from food waste. ACS Sustain. Chem. Eng. 2015, 3, 1047-1055. [CrossRef]

83. Piccinno, F.; Hischier, R.; Seeger, S.; Som, C. Predicting the environmental impact of a future nanocellulose production at industrial scale: Application of the life cycle assessment scale-up framework. J. Clean. Prod. 2018, 174, 283-295. [CrossRef]

84. Arvidsson, R.; Nguyen, D.; Svanström, M. Life Cycle Assessment of Cellulose Nanofibrils Production by Mechanical Treatment and Two Different Pretreatment Processes. Environ. Sci. Technol. 2015, 49, 6881-6890. [CrossRef]

85. De Figueirêdo, M.C.B.; de Freitas Rosa, M.; Ugaya, C.M.L.; de Souza, M.d.S.M.; da Silva Braid, A.C.C.; de Melo, L.F.L. Life cycle assessment of cellulose nanowhiskers. J. Clean. Prod. 2012, 35, 130-139. [CrossRef]

86. Do Nascimento, D.M.; Almeida, J.S.; Vale, M.d.S.; Leitão, R.C.; Muniz, C.R.; de Figueirêdo, M.C.B.; Morais, J.P.S.; Rosa, M.d.F. A comprehensive approach for obtaining cellulose nanocrystal from coconut fiber. Part I: Proposition of technological pathways. Ind. Crop. Prod. 2016, 93, 66-75. [CrossRef]

87. do Nascimento, D.M.; Dias, A.F.; de Araújo Junior, C.P.; de Freitas Rosa, M.; Morais, J.P.S.; de Figueirêdo, M.C.B. A comprehensive approach for obtaining cellulose nanocrystal from coconut fiber. Part II: Environmental assessment of technological pathways. Ind. Crop. Prod. 2016, 93, 58-65. [CrossRef]

88. Hervy, M.; Evangelisti, S.; Lettieri, P.; Lee, K.-Y. Life cycle assessment of nanocellulose-reinforced advanced fibre composites. Compos. Sci. Technol. 2015, 118, 154-162. [CrossRef]

89. Josset, S.; Orsolini, P.; Siqueira, G.; Tejado, A.; Tingaut, P.; Zimmermann, T. Energy consumption of the nanofibrillation of bleached pulp, wheat straw and recycled newspaper through a grinding process. Nord. Pulp Pap. Res. J. 2014, 29, 167-175. [CrossRef]

90. Spence, K.L.; Venditti, R.A.; Rojas, O.J.; Habibi, Y.; Pawlak, J.J. A comparative study of energy consumption and physical properties of microfibrillated cellulose produced by different processing methods. Cellulose 2011, 18, 1097-1111. [CrossRef]

91. Turbak, A.F.; Snyder, F.W.; Sandberg, K.R. Microfibrillated Cellulose, a New Cellulose Product: Properties, Uses, and Commercial Potential. J. Appl. Polym. Sci. Appl. Polym. Symp. 1983, 37, 815-827.

92. Saito, T.; Nishiyama, Y.; Putaux, J.-L.; Vignon, M.; Isogai, A. Homogeneous suspensions of individualized microfibrils from TEMPO-catalyzed oxidation of native cellulose. Biomacromolecules 2006, 7, 1687-1691. [CrossRef]

93. Wågberg, L.; Decher, G.; Norgren, M.; Lindström, T.; Ankerfors, M.; Axnäs, K. The build-up of polyelectrolyte multilayers of microfibrillated cellulose and cationic polyelectrolytes. Langmuir 2008, 24, 784-795. [CrossRef]

94. Eyholzer, C.; Bordeanu, N.; Lopez-Suevos, F.; Rentsch, D.; Zimmermann, T.; Oksman, K. Preparation and characterization of water-redispersible nanofibrillated cellulose in powder form. Cellulose 2010, 17, 19-30. [CrossRef]

95. Bondeson, D.; Mathew, A.; Oksman, K. Optimization of the isolation of nanocrystals from microcrystalline cellulose by acid hydrolysis. Cellulose 2006, 13, 171. [CrossRef]

96. Klemm, D.; Kramer, F.; Moritz, S.; Lindström, T.; Ankerfors, M.; Gray, D.; Dorris, A. Nanocelluloses: A new family of nature-based materials. Angew. Chem. Int. Ed. 2011, 50, 5438-5466. [CrossRef]

97. Klöpffer, W.; Curran, M.A.; Frankl, P.; Heijungs, R.; Köhler, A.; Olsen, S.I. Nanotechnology and Life Cycle Assessment: A Systems Approach to Nanotechnology and the Environment: Synthesis of Results Obtained at a Wrokshop, Washington, DC, USA, 2-3 October 2007; European Commission: Brussels, Belgium, 2007.

98. Khanna, V. Environmental and Risk Assessment at Multiple Scales with Application to Emerging Nanotechnologies; The Ohio State University: Columbus, OH, USA, 2009.

99. Katakojwala, R.; Mohan, S.V. Microcrystalline cellulose production from sugarcane bagasse: Sustainable process development and life cycle assessment. J. Clean. Prod. 2020, 249, 119342. [CrossRef] 